\title{
The Effect of Cordycepin on Steroidogenesis and Apoptosis in MA-10 Mouse Leydig Tumor Cells
}

\author{
Bo-Syong Pan, Chun-Yu Lin, and Bu-Miin Huang \\ Department of Cell Biology and Anatomy, College of Medicine, National Cheng Kung University, Tainan 701, Taiwan \\ Correspondence should be addressed to Bu-Miin Huang, bumiin@mail.ncku.edu.tw
}

Received 9 November 2010; Revised 25 January 2011; Accepted 30 March 2011

Copyright () 2011 Bo-Syong Pan et al. This is an open access article distributed under the Creative Commons Attribution License, which permits unrestricted use, distribution, and reproduction in any medium, provided the original work is properly cited.

\begin{abstract}
Cordycepin is a natural pure compound extracted from Cordyceps sinensis (CS). We have demonstrated that CS stimulates steroidogenesis in primary mouse Leydig cell and activates apoptosis in MA-10 mouse Leydig tumor cells. It is highly possible that cordycepin is the main component in CS modulating Leydig cell functions. Thus, our aim was to investigate the steroidogenic and apoptotic effects with potential mechanism of cordycepin on MA-10 mouse Leydig tumor cells. Results showed that cordycepin significantly stimulated progesterone production in dose- and time-dependent manners. Adenosine receptor (AR) subtype agonists were further used to treat MA-10 cells, showing that $A_{1}, A_{2 A}, A_{2 B}$, and $A_{3}, A R$ agonists could stimulate progesterone production. However, StAR promoter activity and protein expression remained of no difference among all cordycepin treatments, suggesting that cordycepin might activate AR, but not stimulated StAR protein to regulate MA-10 cell steroidogenesis. Meanwhile, cordycepin could also induce apoptotic cell death in MA-10 cells. Moreover, four AR subtype agonists induced cell death in a dose-dependent manner, and four AR subtype antagonists could all rescue cell death under cordycepin treatment in MA-10 cells. In conclusion, cordycepin could activate adenosine subtype receptors and simultaneously induce steroidogenesis and apoptosis in MA-10 mouse Leydig tumor cells.
\end{abstract}

\section{Introduction}

Cordyceps sinensis (CS) is an ingredient of traditional Chinese medicine and is prescribed for replenish the kidney and soothe the lung and for the treatment of fatigue [1]. Cordycepin ( $3^{\prime}$-deoxyadenosine, an adenosine analogue) is a pure component extracted from the mycelia of CS, and it is well known to possess anticancer ability which induce apoptosis in HeLa cells, oral cancer cells, breast cancer cells, leukemia, and lymphoma cell lines [2-5]. Previous studies demonstrated that CS alone could stimulate steroid production in both normal and tumor mouse Leydig cells $[6,7]$ and activate apoptosis in MA-10 mouse Leydig tumor cells [8]. It is highly possible that cordycepin is the main component in CS modulating Leydig cell functions. Thus, the aim of the present study was to investigate the steroidogenic and apoptotic effects with potential mechanism of cordycepin on MA-10 mouse Leydig tumor cells.

Steroidogenesis, steroid hormone biosynthesis, occurs mainly in the adrenal glands, brain, placenta, testes, and ovaries [9]. In the male reproduction system, steroidogenesis in Leydig cells is regulated by luteinizing hormone
(LH)/human chorionic gonadotropin (hCG). LH and hCG activate its cognate receptors and coupling to the adenylate cyclase $(\mathrm{AC})$ through the heterotrimeric guanine nucleotidebinding regulatory protein (G-protein) $[10,11]$. The activated GTP-bound $\alpha$ subunit of G-protein would be able to activate adenylyl cyclase, which results in the hydrolysis of ATP to cyclic AMP. Once cAMP is synthesized, the following activation of protein kinase A (PKA) pathway would phosphorylate steroidogenic acute regulatory protein (StAR) [12]. The StAR protein, a $30 \mathrm{kDa}$ phosphoprotein, is the rate-limiting step which delivers cholesterol from the outer to the inner mitochondrial membrane [13]. After translocation into mitochondrial, P450 side chain cleave enzyme (P450scc) converts cholesterol to pregnenolone [14]. When pregnenolone is formed, it may be metabolized to progesterone by mitochondrial $3 \beta$-hydroxysteriod dehydrogenase $(3 \beta-\mathrm{HSD})$, or it may exit the mitochondria and undergo further metabolism with the final steroid hormone product dependent upon the nature of the tissue $[15,16]$.

It has been well demonstrated that adenosine acts through four G-protein-coupled membrane receptors, the $\mathrm{A}_{1}, \mathrm{~A}_{2 \mathrm{~A}}, \mathrm{~A}_{2 \mathrm{~B}}$, and $\mathrm{A}_{3}$ adenosine receptors [17]. The adenosine 
$A_{1}$ and $A_{3}$ receptors $\left(A_{1}-A R\right.$ and $\left.A_{3}-A R\right)$ inhibit adenylate cyclase via $G_{i}$ and activate phospholipase C (PLC) $[18,19]$, and the adenosine $A_{2 A}$ and $A_{2 B}$ receptors $\left(A_{2 A}-A R\right.$ and $A_{2 B}-$ AR) stimulate adenylyl cyclase via $G_{s}[20,21]$, respectively. It is also shown that adenosine appears to induce cell death through apoptosis, whereas ATP appears to cause both necrosis and apoptosis [22].

Although some reports have showed that cordycepin possesses anticancer ability, there is still no research about cordycepin on gonadal steroidogenesis. In fact, we have demonstrated that cordycepin could stimulate testosterone production in normal mouse primary Leydig cells without any phenomenon of cell death [23]. Since the isolation of primary Leydig cell is complicated with very low yield from mouse testis, MA-10 mouse Leydig tumor cell line was then used to further examine the regulatory mechanisms regarding the effects of cordycepin. Interestingly, we did find that cordycepin could induce MA-10 cell steroidogenesis and apoptosis. Thus, our objective was to investigate the effect of cordycepin on Leydig cell steroidogenesis and apoptosis with the preliminarily possible mechanisms.

\section{Materials and Methods}

2.1. Chemicals. Cordycepin, bovine serum albumin (BSA), Waymouth MB 752/1 medium, N6-cyclopentyladenosine (CPA), 2-p-(2-carboxyethyl) phenethylamino- $5^{\prime}-N$-ethylcarboxamidoadenosine (CGS-21680), 5'-N-ethylcarboxamidoadenosine (NECA), N6-(3-iodobenzyl) adenosine5'-N-methyluronamide (IB-MECA), 8-Cyclopentyl1,3-dipropylxanthine (DPCPX), 8-(3-Chlorostyryl) caffeine (CSC), 8-[4-[((4-Cyanophenyl)carbamoylmethyl)oxy] phenyl]-1,3di(n-propyl) xanthine (MRS 1754), 3-Ethyl-5-benzyl-2methyl-4-phenylethylethynyl-6-phenyl-1,4-dihydropyridine-3,5-dicarboxylate (MRS 1191), human chorionic gonadotropin (hCG) (10,000 IU per gram) and methylthiazolecterazoli-um (MTT) were purchased from Sigma Chemical (St. Louis, mo, USA). Fetal bovine serum (FBS), Dulbecco's phosphate-buffered saline, lyophilized trypsin-EDTA, and gentamicin sulfate were purchased from Gibco (Grand Island, NY, USA). Sodium hydroxide, hydrochloric acid, Sodium dodecyl sulfate (SDS), sucrose, EDTA, isopropyl alcohol, chloroform, and Tween 20 were purchased from Merck (Darmstadt, Germany). Tris base was purchased from Calbiochem (San Deigo, Calif, USA). Acrylamide was purchased from J.T. Baker (Phillipsburg, NJ, USA). HEPES was purchased from Mallinckrodt Baker, Inc. (Paris, USA). Tissue culture grade sodium bicarbonate, sodium carbonate, sodium chloride, sodium dihydrogen phosphate, and potassium chloride were purchased from Riedel-deHaen (Seelze, Germany). dNTP and MMLV reverse transcriptase were purchased from Promega (Madison, Wis, USA). Taq was purchased from ABgene (Surrey, UK). Donkey antirabbit IgG conjugated with horseradish peroxidase were purchased from Amersham International (Arlington Heights, Ill, USA). Antibody against $\beta$-actin was purchased from Cell Signaling (Beverly, USA). Antibody against StAR was a generous gift from Dr. Strauss (University of Pennsylvania Medical Center, USA).
Charcoal was purchased from Showa Chemical Inc. (Tokyo, Japan). $\left[{ }^{3} \mathrm{H}\right]$ progesterone used for radioimmunoassay was purchased from Dupont-New England Nuclear (Boston, USA). Antiserum to progesterone was a kind gift from Dr. Paulus S. Wang (National Yang Ming University, Taipei, Taiwan).

2.2. Cell Culture. The MA-10 cell line was a gift from Dr. Mario Ascoli (The University of Iowa, Iowa City, USA) and is maintained at $37^{\circ} \mathrm{C}$ in a humidified environment containing $95 \%$ air and $5 \% \mathrm{CO}_{2}$ for all the following experiments. MA- 10 cells $\left(5 \times 10^{3}\right.$ cells $/ 100 \mu \mathrm{L}$ medium $)$ or $\left(6 \times 10^{5}\right.$ cells $/ 2 \mathrm{~mL}$ medium) were plated into 96 -well plates or $6 \mathrm{~cm}$ dish grown for $24 \mathrm{hr}$ in Waymouth medium containing $10 \%$ fetal bovine serum, respectively. The medium was removed and the cells were washed twice with 1X PBS, and then treated with various concentrations of cordycepin in serum free Waymouth medium for indicated time periods. The cells were then isolated for total protein. The expression of target protein was determined by Western blot analysis. Cytotoxicity assay and cell morphological analysis of the MA-10 cells were determined by MTT assay. The media were withdrawn and progesterone levels were determined by radioimmunoassay. Finally, the adenosine receptor subtypes mRNA expression were performed by RT-PCR.

2.3. Morphology Study. MA-10 cells were seeded in 96-well plate (Techno Plastic Products AG, Trasadingen, Switzerland) containing $5 \times 10^{3}$ cells with $100 \mu \mathrm{L}$ serum medium in each well. After 70-80\% confluence, cells were treated without or with $100 \mu \mathrm{M}$ and $1 \mathrm{mM}$ cordycepin for $24 \mathrm{hr}$, respectively. Cell morphology was then observed and recorded under light microscopy (Olympus, CK40). Apoptosis was characterized by the loss of cellular contact with the matrix and the appearance of plasma membrane blebbing.

2.4. MTT Cytotoxicity Assay. Cordycepin-induced MA-10 cells cytotoxicity was determined by measuring mitochondrial succinate dehydrogenase activity using a modification of the MTT assay. After MA- 10 cells reach $70 \%-80 \%$ confluence, cells were treated with serum free medium containing $100 \mu \mathrm{M}$ and $1 \mathrm{mM}$ cordycepin for indicated time points (24 and $48 \mathrm{hr}$ ). MTT was added to wells $(0.5 \mathrm{mg} / \mathrm{mL}$ final concentration) after time points of culture at $37^{\circ} \mathrm{C}$ in a $5 \%$ $\mathrm{CO}_{2}$ humidified atmosphere in the presence of the desired reagents. Mitochondrial dehydrogenases of viable cells will convert MTT into a color-dense formazan. Four hours later, the DMSO was added in wells to dissolve the formazan. The DMSO solutions were added and the absorbance was measured at $590 \mathrm{~nm}$ by an ELISA reader (VersaMax, MDS Inc., Toronto, Canada).

2.5. DNA Fragmentation Assay. Cells $\left(1 \times 10^{6}\right)$ were lysed in a $0.6 \mathrm{~mL}$ cell lysis solution containing $20 \mathrm{mM}$ Tris- $\mathrm{HCl}$, $10 \mathrm{mM}$ EDTA, pH 8.0 and $0.3 \%$ Triton X-100. DNA was extracted with $0.6 \mathrm{~mL}$ phenol/chloroform $(1: 1)$, and the mixture was centrifuged at $12,500 \mathrm{rpm}$ for $10 \mathrm{~min}$. DNA in the aqueous phase was extracted with phenol/chloroform 
(1:1) again. The aqueous (DNA containing) phase was mixed with isopropanol at $-20^{\circ} \mathrm{C}$ overnight. After centrifugation, DNA pellets were washed with $70 \%$ ethanol and air-dried. DNA pellets were dissolved in TE buffer (10 mM Tris- $\mathrm{HCl}, 1 \mathrm{mM}$ EDTA, $\mathrm{pH} 8.0$ ), and RNase A $\left(3 \mathrm{mg} / \mathrm{mL}\right.$ ) was added to remove RNA at $37^{\circ} \mathrm{C}$ for $30 \mathrm{~min}$. DNA electrophoresis was carried out in 2\% agarose gel. The gel was stained with ethidium bromide. DNA fragments were visualized by exposing the gel to UV light.

2.6. Reverse Transcription-Polymerase Chain Reaction (RT$P C R$ ). Total RNA was isolated from MA-10 cells using Trizol reagent as recommended by the manufacturer (Invitrogen, Carlsbad, Calif, USA). Reverse transcription was performed in a mixture containing $5 \mu \mathrm{M}$ random primer, $200 \mu \mathrm{M} \mathrm{dNTP \text {, }}$ $2 \mathrm{U} / \mu \mathrm{L}$ MMLV reverse transcriptase together with $5 \mu \mathrm{L}$ tRNA as the template. The corresponding buffer was performed at $42^{\circ} \mathrm{C}$ for $90 \mathrm{~min}$ followed by $95^{\circ} \mathrm{C}$ for $10 \mathrm{~min}$. PCR was performed in a mixture containing $2 \mu \mathrm{L} 10 \mathrm{X}$ PCR buffer, $0.4 \mu \mathrm{L} 10 \mathrm{mM}$ dNTP, $0.4 \mu \mathrm{L} 20 \mathrm{mM}$ specific forward and reverse primers (primer sequence and corresponding sequence of specific genes were listed in Table 1), $14.7 \mu \mathrm{L}$ $\mathrm{ddH}_{2} \mathrm{O}, 0.1 \mu \mathrm{L} 0.5 \mathrm{U}$ Taq with $2 \mu \mathrm{L}$ RT product as template for each reaction. Thermocontrolling program was set up as the following: denature at $95^{\circ} \mathrm{C}$ for $30 \mathrm{sec}$, annealing at $55^{\circ} \mathrm{C}$ for $30 \mathrm{sec}$, elongation at $72^{\circ} \mathrm{C}$ for $30 \mathrm{sec}$ with another $5 \mathrm{~min}$ of elongation at $72^{\circ} \mathrm{C}$. The whole mixture was subjected to 30 cycles for amplification of $L 19,32$ cycles for amplification of $A_{1}-A R, 34$ cycles for amplification of $A_{2 A}-A R$ and $A_{2 B}-A R$ and 38 cycles for amplification of $\mathrm{A}_{3}-\mathrm{AR}$. The PCR product was then separated on a $1.5 \%$ agarose gel at $120 \mathrm{~V}$ for $30 \mathrm{~min}$ in 1X TBE buffer $(0.09 \mathrm{M}$ Tris, $0.09 \mathrm{M}$ boric acid, $0.001 \mathrm{M}$ EDTA, pH 8.0). The gel was then stained with ethidium bromide for $10 \mathrm{~min}$ and destained with mili-Q water. The gel image was captured by using Labwork imager system (Digital CCD Camera, Hamamtsu Photonics system, Bridgewater, USA).

2.7. Radioimmunoassay (RIA). Media from cultures with different treatments were harvested. Twenty $\mu \mathrm{L}$ of sample was loaded into a glass tube and $100 \mu \mathrm{L}$ each of progesterone antiserum and ${ }^{3} \mathrm{H}$ progesterone were loaded. Equilibrium reaction occurred at $37^{\circ} \mathrm{C}$ for $30 \mathrm{~min}$ and was stopped by putting the tubes in ice. Charcoal was added into the tubes at $4^{\circ} \mathrm{C}$ for $15 \mathrm{~min}$ and centrifuged for $10 \mathrm{~min}$ in order to spin down the charcoal- ${ }^{3} \mathrm{H}$ progesterone complex. The supernatant was poured into $2 \mathrm{~mL}$ of scintillation fluid and samples would be counted in a $\beta$-counter (LS 5000TA, Beckman Inc., Fullerton, Calif, USA).

2.8. Immunoblot Analysis. $6.0 \times 10^{5}$ cells were cultured in $6 \mathrm{~cm}$ dish. After treatment, cells were rinsed with cold PBS. Then, the cells were harvested by $100 \mu \mathrm{L}$ lysis buffer (20 mM Tris-base, 150 mM NaCl, 1 mM EDTA, 1 mM EGTA, $1 \%$ Triton X-100, $2.5 \mathrm{mM}$ Sodium pyrophosphate, $1 \mathrm{mM}$ beta-Glycerolphosphate, $1 \mathrm{mM} \mathrm{Na}_{3} \mathrm{VO}_{4}$ ). The cell lysate was subjected to centrifugation at $12,000 \times \mathrm{g}$ for $12 \mathrm{~min}$ at $4^{\circ} \mathrm{C}$. The supernatant was stored at $-20^{\circ} \mathrm{C}$ until used. The
TABLE 1: Sequence of primers used for reverse transcription-polymerase chain reaction (RT-PCR).

\begin{tabular}{llr}
\hline & \multicolumn{1}{c}{ Sequence $\left(5^{\prime}\right.$ to $\left.3^{\prime}\right)$} & PCR size \\
\hline L19 & F GAA ATC GCC AAT GCC AAC TC & 405 b.p. \\
& R TCT TAG ACC TGC GAG CCT CA & \\
& F CGG GAT CCT ACA TCT CGG CCT TCC & \\
A $_{1}$-AR & AGG & 219 b.p. \\
& R GGA ATT CAG TAG GTC TGT GGC & \\
& CCA ATG & \\
& F CGG GAT CCG TCC CTG GCC ATC ATC & \\
A $_{2 \mathrm{~A}}$-AR & GT & \\
& R GGA ATT CGA TCC TGT AGG CGT & \\
& AGA T & \\
& F CGG GTA CCC CTC GAG TGC ATT ACA & \\
A $_{2 \mathrm{~B}-\text { AR }}$ & GA & \\
& R CCG CCG AAA CCT TTA TAC CTG AGC & \\
& F CGG GAT CCC GTT CCG TGG TCA & \\
A $_{3}$-AR & GTT TGR GGA ATT CGC AGG CGT AGA & 384 b.p. \\
& CAA TAG G & \\
\hline
\end{tabular}

protein concentration was determined by Lowry method [24]. Total proteins were separated in 12.5\% SDS-PAGE. Electrophoresis was performed in SDS-PAGE running buffer (24 mM Tris/HCl, 0.19M glycine, 0.5\% SDS, $\mathrm{pH} 8.3$ ). The proteins were transferred to polyvinylidene difluoride membranes (PVDF) in transfer buffer $(20 \mathrm{mM}$ Tris/ $\mathrm{HCl}$, $150 \mathrm{Mm}$ glycine, $10 \%$ methanol, $0.05 \%$ SDS). The PVDF membrane with protein on it was incubated in blocking buffer (TBS buffer containing 5\% Carnation non-fat dry milk and $0.1 \%$ Tween-20) at room temperature for an hour. After washing, the membrane would be incubated in primary antibodies StAR at 1:2500 dilutions overnight at $4^{\circ} \mathrm{C}$. The membrane would be washed three times ( $10 \mathrm{~min}$ each) with TBS containing $0.1 \%$ Tween-20. It was then incubated for an hour at room temperature with fresh blocking buffer containing the secondary antibody, antirabbit IgG. The membrane was washed and the signal detected by using the Renaissance chemiluminescence reagent. The desired protein was quantitated by UVP EC3 Imaging System (Upland, Calif, USA). The amount of $\beta$-actin in each lane was detected and quantified as well in order to normalize the expression of target protein.

2.9. Transient Transfection and Luciferase Assays. The $5^{\prime}-$ flanking regions $(-1278 /+32)$ of the mouse StAR gene were cloned into the $p G L 3$ basic vector (Promega Corp., Madison, Wis, USA), upstream of a luciferase reporter gene utilizing the XhoI and HindIII sites. The plasmid $p S V$ Galactosidase control vector (Promega Corp.) was used to normalize transfection efficiency. Plasmids were transfected using Lipofectamine 2000 (Invitrogen 11668-019, Invitrogen Corp., Calif, USA). In brief, $1.2 \times 10^{5}$ cells $/ 500 \mu \mathrm{L}$ medium were cultured in either 24 -well plates to $65-75 \%$ confluency and transfected using $0.5 \mu \mathrm{g}$ of plasmid in the presence of $0.5 \mu \mathrm{g}$ of $p S V$-Galactosidase control vector. After $6 \mathrm{hr}$ of transfection, MA-10 cells were followed by rising and incubation in serum-free Waymouth medium for $18 \mathrm{hr}$. After 
medium was changed, cells were then treated with cordycepin for another $12 \mathrm{hr}$. Luciferase assays were performed using the Luciferase Reporter Assay System according to the manufacturer's instructions (Promega Corp., Madison, Wis, USA). Briefly, after treatment cells were washed with $1 \mathrm{X}$ PBS and $200 \mu \mathrm{L}$ of the $1 \mathrm{X}$ passive lysis buffer (DualLuciferase Reporter Assay System, Promega E1910, Promega Corp., Madison, Wis, USA) was added to the plates. The cellular debris was pelleted by centrifugation at $12,000 \times \mathrm{g}$ at $4^{\circ} \mathrm{C}$, and the $20 \mu \mathrm{L}$ supernatant was measured for $50 \mu \mathrm{L}$ Luciferase Assay Buffer (Dual-Luciferase Reporter Assay System, Promega E1910, Promega Corp., Madison, Wis, USA) in a MiniLumat Luminometer (Turner Designs Corp., Sunnyvale, Calif, USA).

2.10. Statistical Analysis. Each data point in the figures represents the mean \pm SEM of three or four separate experiments. Statistically significant differences between treatments and controls were determined by one-way ANOVA and then least significance difference (LSD) or with $t$-test comparison procedure. Statistical significance was set at $P<.05$.

\section{Results}

3.1. Effects of Cordycepin on Steroidogenesis in MA-10 Mouse Leydig Tumor Cells. To test the hypothesis that cordycepin influences the production of steroid hormone in MA-10 mouse Leydig tumor cells; we initially determined the effect of cordycepin on the production of progesterone. MA-10 cells were incubated with different dosages $(1,10,100 \mu \mathrm{M}$, and $1 \mathrm{mM}$ ) of cordycepin for $24 \mathrm{hr}$. Results showed that the progesterone production induced by $100 \mu \mathrm{M}$ cordycepin was more than 3 folds significantly compared to the control $(217.5 \pm 101.7$ versus $675.9 \pm 185.4 \mathrm{pg} / \mu \mathrm{g}$ protein; $P<.05)$ (Figure 1(a)). As shown in Figure 1(b), cordycepin at $100 \mu \mathrm{M}$ significantly stimulated progesterone to a maximum at $24 \mathrm{hr}$ $(P<.05)$. According to the results, $100 \mu \mathrm{M}$ cordycepin for $24 \mathrm{hr}$ treatment was used to investigate the possible cellular mechanism.

3.2. RT-PCR Analysis for Detection of $A_{1}, A_{2 A}, A_{2 B}$, and $A_{3}$ Adenosine Receptor $m R N A$ Transcripts in MA-10 Mouse Leydig Tumor Cells. It has been reported that cordycepin could inhibit lung carcinoma and melanoma cell growth by stimulating $A_{3}-A R[25,26]$. We hypothesized for the presence of functional adenosine receptor subtypes that involved in cordycepin-induced steroidogenesis in MA-10 cells. Thus, mRNA expressions of all four AR subtypes, $A_{1}, A_{2 A}, A_{2 B}$, and $A_{3}$, with cordycepin treatment in MA10 cells were analyzed by RT-PCR. The results showed that cordycepin $(100 \mu \mathrm{M}$ and $1 \mathrm{mM})$ could change the mRNA expression among four AR subtypes (Figure 2(a)). The normalized results showed that the treatment of $1 \mathrm{mM}$ cordycepin for $24 \mathrm{hr}$ upregulated the expression of A1-AR mRNA for about 1.5 fold $(P<.05)$ (Figure $2(\mathrm{~b})$ ). Cordycepin $(1 \mathrm{mM})$ upregulated the expression of $\mathrm{A}_{2 \mathrm{~A}}-\mathrm{AR}$ mRNA for about 2 folds $(P<.05)$ (Figure $2(\mathrm{c})$ ). Cordycepin at $1 \mathrm{mM}$ would also upregulate the expression of $A_{3}-A R$ mRNA for

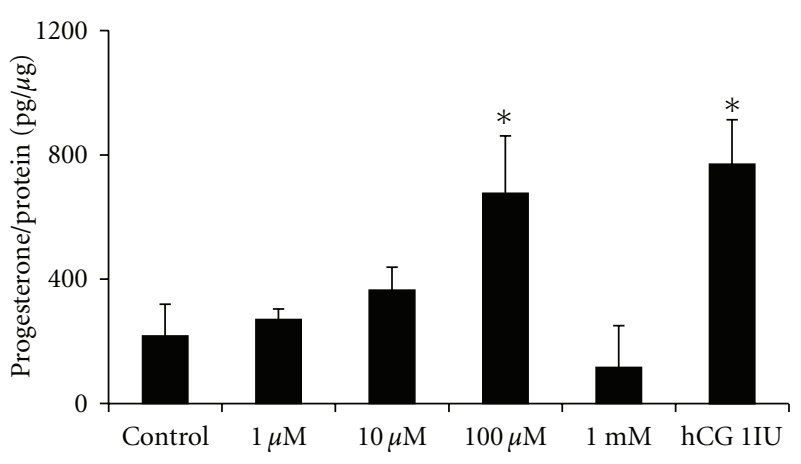

(a)

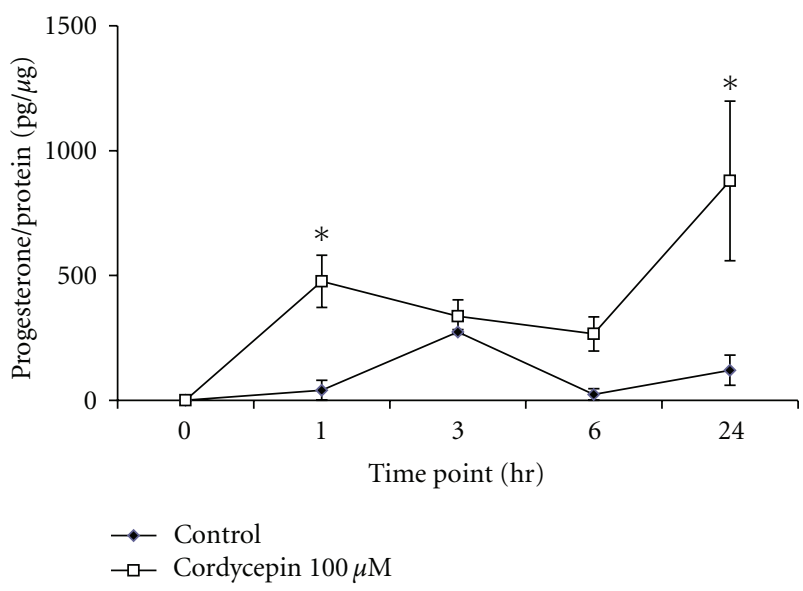

(b)

Figure 1: Dose- and time-course effects of cordycepin on steroidogenesis in MA-10 mouse Leydig tumor cells. MA-10 cells (5000 cells/well) were treated with $1,10,100 \mu \mathrm{M}$ and $1 \mathrm{mM}$ cordycepin for $24 \mathrm{hr}$ (a); and MA-10 cells were treated with $100 \mu \mathrm{M}$ cordycepin for $0,1,3,6$, and $24 \mathrm{hr}$ (b), respectively. Treatment of hCG ( $1 \mathrm{IU})$ was used as a positive control. Media were collected and assayed for progesterone production by RIA. Each data point in the figure represents the mean the mean \pm SEM of three independent experiments with triplicates in each treatment. Asterisk $*(P<$ $.05)$ above the bars indicates significant difference compared with control.

about 3 folds $(P<.05)$ (Figure 2(e)). However, both $100 \mu \mathrm{M}$ and $1 \mathrm{mM}$ cordycepin would downregulate $\mathrm{A}_{2 \mathrm{~B}}-\mathrm{AR}$ mRNA expression by $60 \%$ and $80 \%$, respectively $(P<.05)$ (Figure 2(d)).

3.3. $A_{1}, A_{2 A}, A_{2 B}$, and $A_{3} A R$ Were Involved in CordycepinInduced Steroidogenesis in MA-10 Mouse Leydig Tumor Cells. By using AR agonists $(1 \sim 100 \mu \mathrm{M})$ to treat MA-10 cells for $24 \mathrm{hr}$, the results showed that $\mathrm{A}_{1^{-}}, \mathrm{A}_{2 \mathrm{~A}^{-}}, \mathrm{A}_{2 \mathrm{~B}^{-}}$, and $\mathrm{A}_{3^{-}}$ $\mathrm{AR}$ agonists could stimulate progesterone production in MA-10 mouse Leydig cells $(P<.05)$ (Figures 3(a)-3(d)). Compared to the control, $\mathrm{A}_{1}-\mathrm{AR}$ agonist could significantly stimulate progesterone production and reach 4.1 folds by $100 \mu \mathrm{M}$ CPA $(P<.05)$ (Figure 3(a)). $\mathrm{A}_{2 \mathrm{~A}}-\mathrm{AR}$ agonist could significantly stimulate progesterone production and reach 6.8 and 7.9 folds by 10 and $25 \mu \mathrm{M}$ CGS-21680, respectively, $(P<.05)$ (Figure $3(\mathrm{~b}))$. $\mathrm{A}_{2 \mathrm{~B}}-\mathrm{AR}$ agonist could 


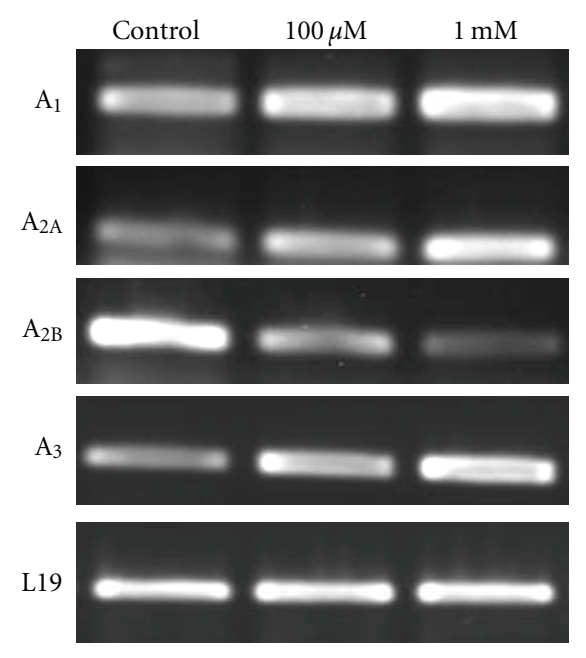

(a)

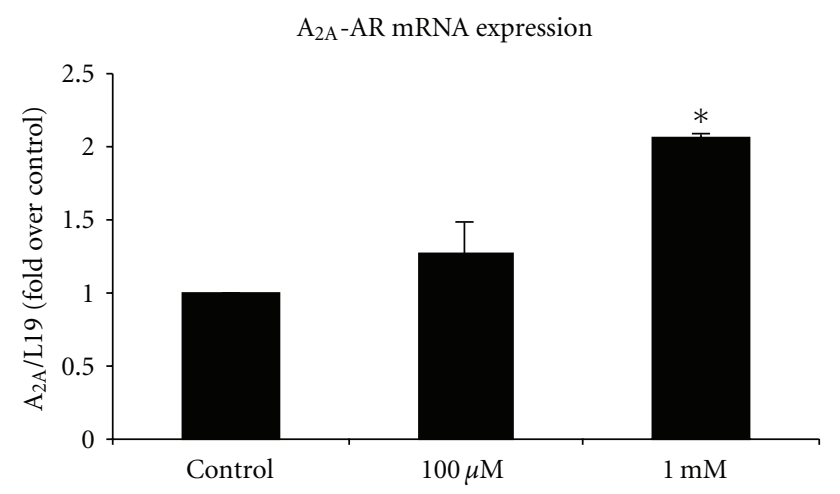

(c)

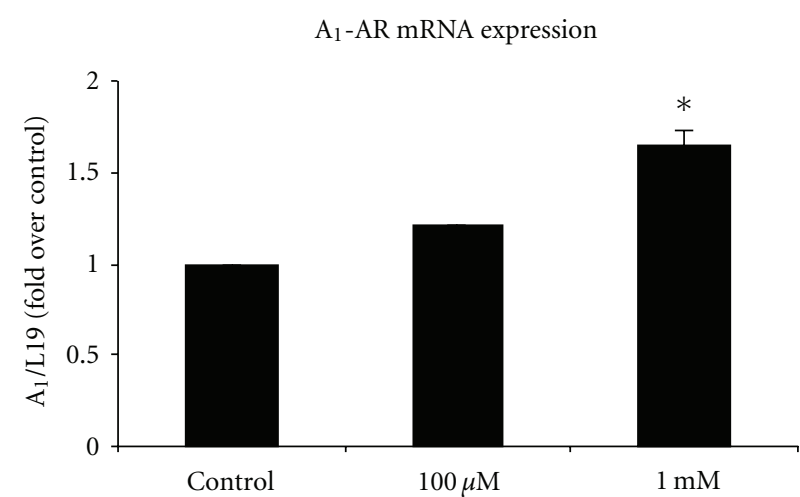

(b)

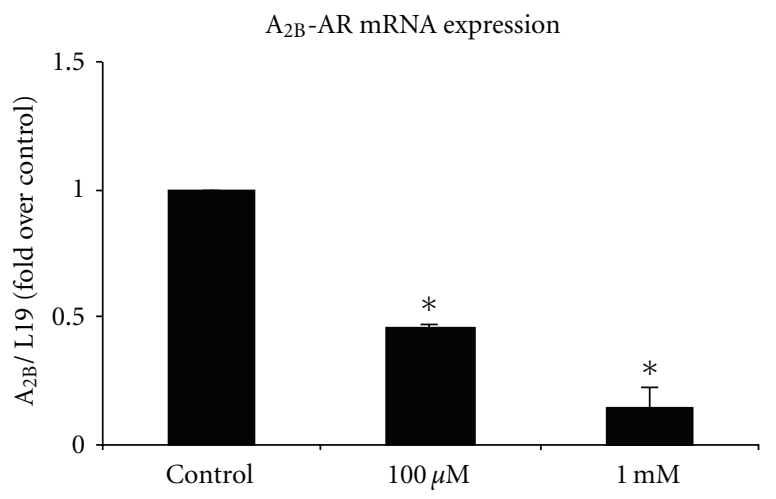

(d)

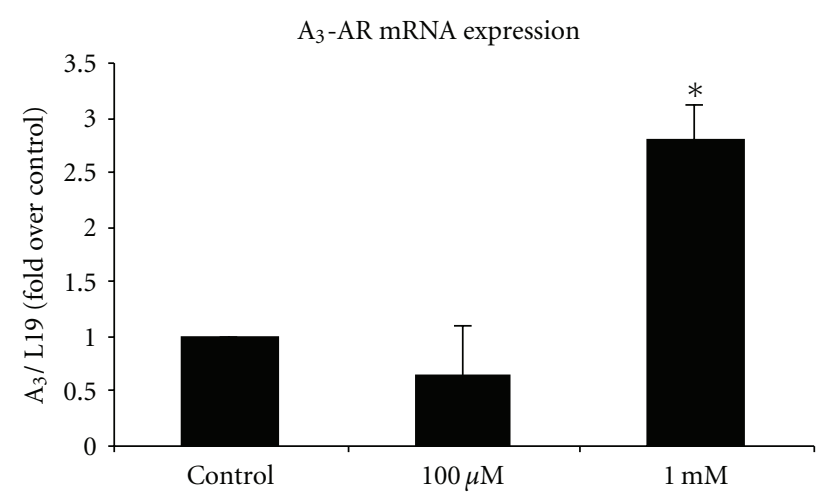

(e)

Figure 2: Characterization of $\mathrm{A}_{1}, \mathrm{~A}_{2 \mathrm{~A}}, \mathrm{~A}_{2 \mathrm{~B}}$, and $\mathrm{A}_{3} \mathrm{AR}$ mRNA expression in MA-10 mouse Leydig tumor cells. MA-10 cells ( $\left.1 \times 10^{6}\right)$ were cultured in Waymouth medium to $80 \%$ confluence, and then the total RNA were extracted and the expression of adenosine receptor subtypes mRNA were analyzed by RT-PCR. (a) shows $A_{1}, A_{2 A}, A_{2 B}$, and $A_{3} A R$ mRNA expression in response to cordycepin at different dosages $(100 \mu \mathrm{M}$ and $1 \mathrm{mM}$ ) for $24 \mathrm{hr}$. $L 19$ is the housekeeping gene used as an internal control. (b) shows the integrated optical density (IOD) of $A_{1}, A_{2 A}, A_{2 B}$, and $A_{3} A R$ mRNA expression after normalization with L19. Each data point in the figure represents the mean \pm SEM of three separate experiments. Asterisk * $(P<.05)$ above the bars indicates significant difference compared with control.

significantly stimulate progesterone production and reach 7.6, 8.9, and 9.8 folds by 1,10 , and $100 \mu \mathrm{M}$ NECA, respectively, $(P<.05)$ (Figure $3(\mathrm{c})) . \mathrm{A}_{3}-\mathrm{AR}$ agonist could significantly stimulate progesterone production and reach 10.5 and 24.7 folds by 10 and $50 \mu \mathrm{M}$ IB-ECA, respectively $(P<.05)$ (Figure 3(d)). On the other hand, cordycepin
$(100 \mu \mathrm{M})$ cotreated with $\mathrm{A}_{1}$-AR agonist would significantly decrease CPA-stimulated $(100 \mu \mathrm{M})$ progesterone production by $47 \%(P<.05)$ (Figure $3(\mathrm{a}))$. Cordycepin $(100 \mu \mathrm{M})$ cotreated with $\mathrm{A}_{2 \mathrm{~B}}$-AR agonist would significantly decrease NECA-stimulated $(1,10$ and $100 \mu \mathrm{M})$ progesterone production by $70 \%, 69 \%$, and $47 \%$, respectively, $(P<.05)$ 


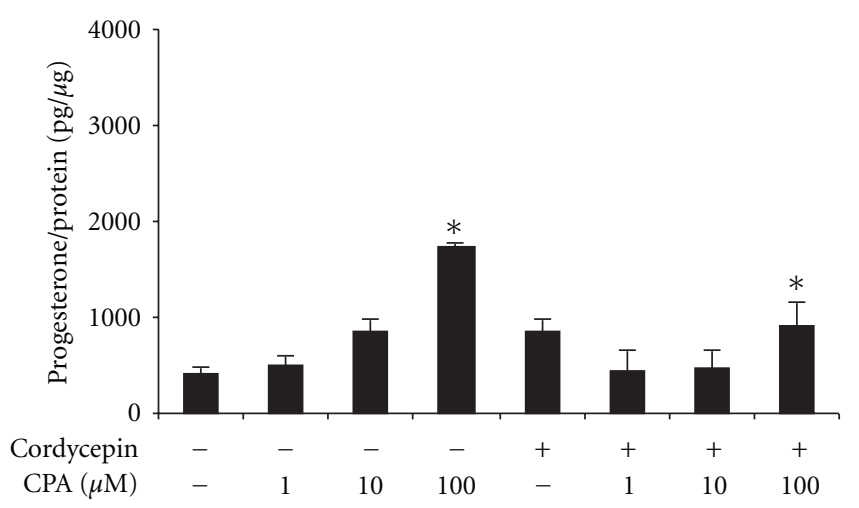

(a)

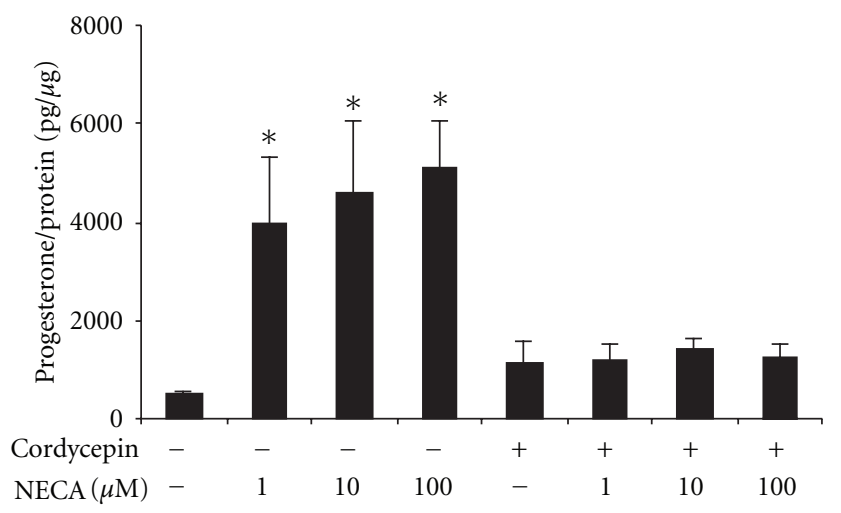

(c)

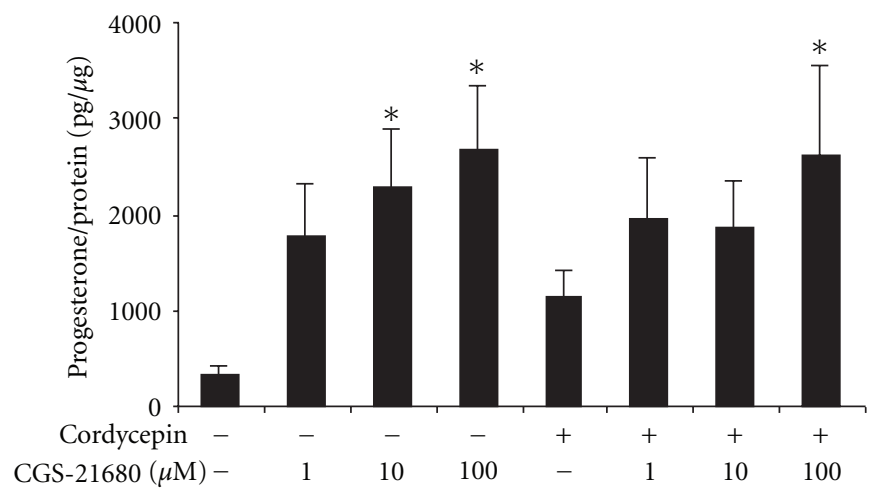

(b)

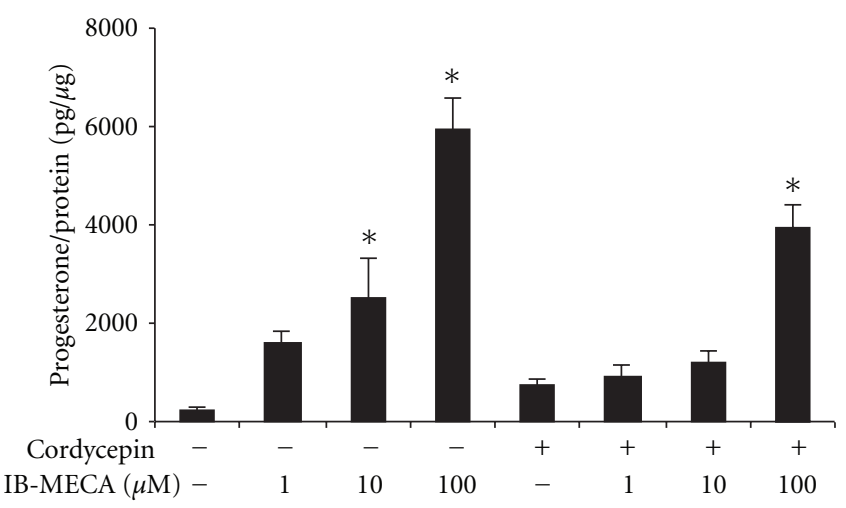

(d)

FIgure 3: $A_{1}, A_{2 A}, A_{2 B}$, and $A_{3} A R$ are involved in cordycepin-induced steroidogenesis. MA-10 cells (5000 cells/well) were treated with different dosage $(1 \sim 100 \mu \mathrm{M})$ of $A_{1}, A_{2 A}, A_{2 B}$, and $A_{3}$ AR agonists, which were (a) CPA, (b) CGS-21680, (c) NECA, and (d) IB-MECA in the absence or presence of $100 \mu \mathrm{M}$ cordycepin for $24 \mathrm{hr}$. Media were collected and assayed for progesterone production by RIA. Each data point in the figure represents the mean the mean \pm SEM of three independent experiments with triplicates in each treatment. Asterisk $*(P<.05)$

above the bars indicates significant difference compared with control.

(Figure 3(c)). Cordycepin $(100 \mu \mathrm{M})$ cotreated with $\mathrm{A}_{3}-\mathrm{AR}$ agonist would significantly decrease IB-MECA $(50 \mu \mathrm{M})$ stimulated progesterone production by $33 \%(P<.05)$ (Figure 3(d)). However, cordycepin $(100 \mu \mathrm{M})$ cotreated with $\mathrm{A}_{2 \mathrm{~A}}$-AR agonist would not affect CGS-21680-stimulated progesterone production $(P>.05)$ (Figure 3(b)). These results demonstrated that cordycepin could regulate AR subtype expressions to stimulate progesterone production in MA-10 cells. To further understand the mechanism of functional AR subtypes that involved in the cordycepininduced steroidogenesis in MA-10 mouse Leydig tumor cells, selective $A_{1^{-}}, A_{2 A^{-}}, A_{2 B^{-}}$, and $A_{3}-A R$ subtype antagonists $(10 \mathrm{nM} \sim 1 \mu \mathrm{M})$ were used to cotreat with cordycepin for $24 \mathrm{hr}$. The results showed that $\mathrm{A}_{1^{-}}, \mathrm{A}_{2 \mathrm{~A}^{-}}, \mathrm{A}_{2 \mathrm{~B}^{-}}$, and $\mathrm{A}_{3}-\mathrm{AR}$ antagonists did not have inhibitory effect on cordycepininduced progesterone production in MA-10 cells $(P>.05)$ (Figures $4(\mathrm{a})-4(\mathrm{~d})$ ).

\subsection{Effects of Cordycepin on StAR Protein and Promoter} Expressions in MA-10 Mouse Leydig Tumor Cells. It has been previously shown that steroidogenesis induced by Cordycep sinensis in MA-10 cells requires de novo protein synthesis [27]. To further understand the mechanism of cordycepin-induced steroidogenesis in MA-10 cells, StAR protein expression was investigated by Western blotting analysis. MA-10 cells were incubated with different dosages $(1 \sim 100 \mu \mathrm{M})$ of cordycepin for $3 \mathrm{hr}$ or $100 \mu \mathrm{M}$ cordycepin for $1,3,6$, and $12 \mathrm{hr}$, respectively. Results showed that the expression of StAR protein was not activated by cordycepin with different dosages (Figure 5(a)) and different time treatments (Figure 5(b)) in MA-10 mouse Leydig tumor cells $(P>.05)$.

In addition, MA-10 cells were transiently transfected with plasmid containing luciferase gene with $5^{\prime}$-flanking StAR promoter constructs between $-1.3 \mathrm{k}$ to +32 regions, and cordycepin $(100 \mu \mathrm{M})$ was added for $12 \mathrm{hr}$ treatment. Results of $5^{\prime}$-deletion promoter analysis indicated that cordycepin did not increase StAR promoter activity $(P>.05)$ (Figure 5(c)). Taken together, these results suggest that StAR protein and StAR promoter might not be involved in the cordycepin-induced steroidogenesis in MA-10 cells.

3.5. Effects of Cordycepin and Adenosine on Cell Death in MA10 Mouse Leydig Tumor Cells. According to our previous 


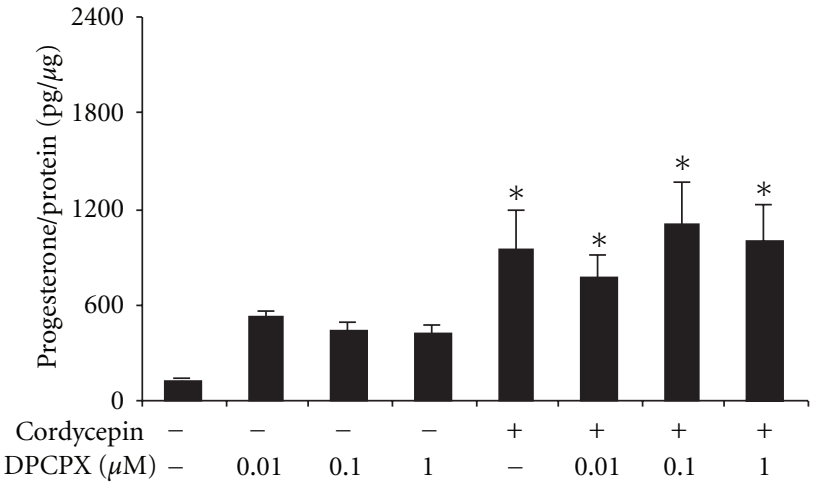

(a)

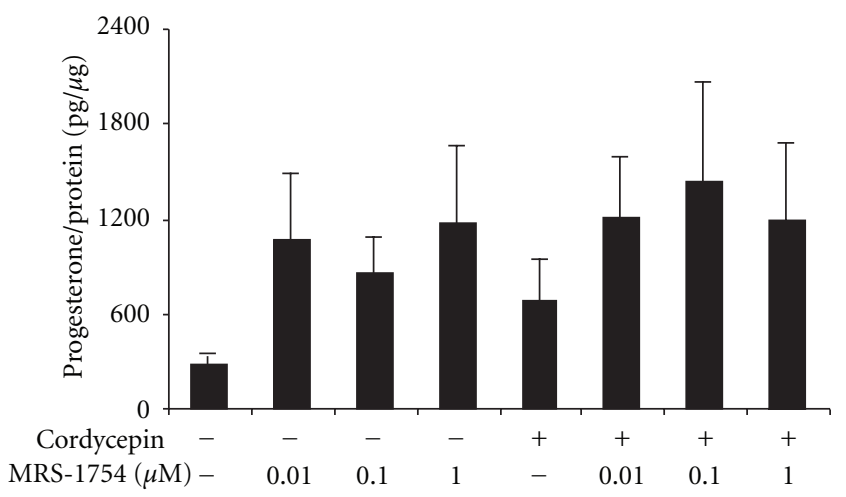

(c)

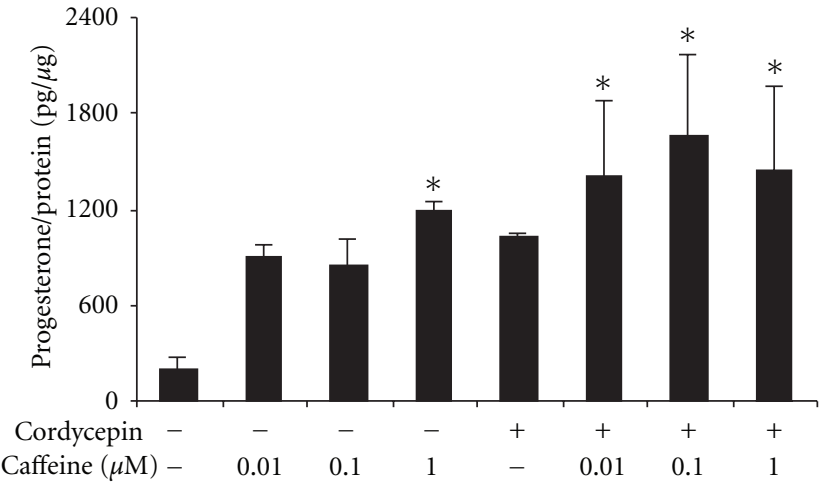

(b)

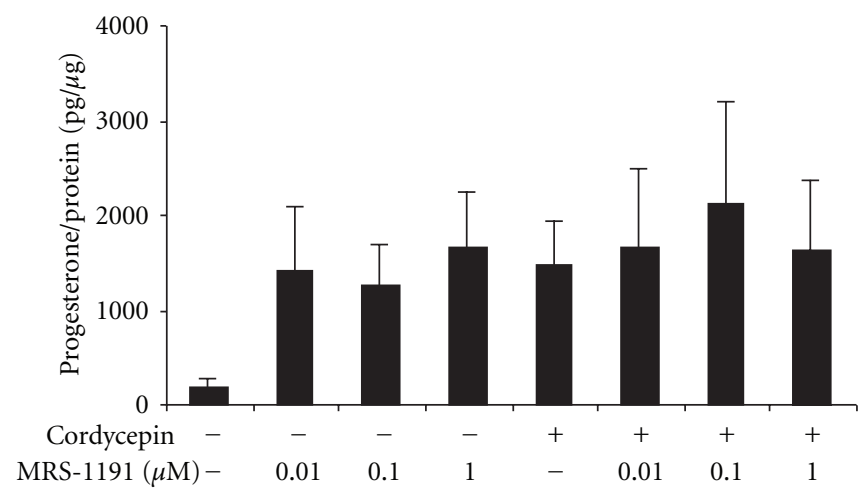

(d)

FIGURE 4: Effects of AR antagonists on cordycepin-induced steroidogenesis in MA-10 mouse Leydig tumor cells. MA-10 cells (5,000 cells/well) were treated with different dosage ( $10 \mathrm{nM} \sim 1 \mu \mathrm{M}$ ) of $\mathrm{A}_{1}, \mathrm{~A}_{2 \mathrm{~A}}, \mathrm{~A}_{2 \mathrm{~B}}$, and $\mathrm{A}_{3}$ AR antagonists, which were (a) DPCPX, (b) Caffeine, (c) MRS-1754, and (d) MRS-1191 in the absence or presence of $100 \mu \mathrm{M}$ cordycepin for $24 \mathrm{hr}$. Media were collected and assayed for progesterone production by RIA. Each data point in the figure represents the mean the mean \pm SEM of three independent experiments with triplicates in each treatment. Asterisk * $(P<.05)$ above the bars indicates significant difference compared with control.

studies, cordycepin has antitumor activity in OECM-1 oral cancer and MA-10 mouse Leydig tumor cell lines [3, 28]. We hypothesized that cordycepin, an adenosine analogue, might act through AR to induce cell death in MA-10 mouse Leydig tumor cells. Thus, the death effects of cordycepin and adenosine on MA-10 cell line was investigated by culturing MA-10 cells with different dosage of adenosine $(10 \mu \mathrm{M} \sim$ $10 \mathrm{mM})$ and cordycepin $(100 \mu \mathrm{M} \sim 1 \mathrm{mM})$ for comparison. MTT assay showed that $1,2,5$, and $10 \mathrm{mM}$ adenosine significantly decreased MA-10 cell viability to $78 \%, 65 \%$, $43 \%$, and $39 \%(P<.05)$, and cordycepin $(100 \mu \mathrm{M}$ and $1 \mathrm{mM})$ significantly decreased MA- 10 cell viability to $44 \%$ and $13 \%(P<.05)$ for $48 \mathrm{hr}$ treatment, respectively (Figure 6(a)). DNA fragmentation was also observed in the MA-10 cells with $10 \mathrm{mM}$ adenosine after $48 \mathrm{hr}$ treatment (Figure 6(b)). The results are comparable regarding the cell death effects between cordycepin and adenosine on MA-10 cells.

3.6. $A_{1}, A_{2 A}, A_{2 B}$, and $A_{3} A R$ Were Involved in CordycepinInduced Cell Death in MA-10 Mouse Leydig Tumor Cells. Previous data demonstrate that expressions of AR subtypes,
$A_{1}, A_{2 A}, A_{2 B}$, and $A_{3}$ mRNA are found in MA-10 cells, and their expression could be modulated by the presence of cordycepin. To investigate whether cordycepin-induced apoptosis was mediated via adenosine receptors on MA-10 mouse Leydig tumor cells, cells were treated with $\mathrm{A}_{1^{-}}, \mathrm{A}_{2 \mathrm{~A}^{-}}$, $\mathrm{A}_{2 \mathrm{~B}^{-}}$, and $\mathrm{A}_{3}-\mathrm{AR}$ agonists (CPA, CGS-21680, NECA and IBMECA) for $24 \mathrm{hr}$, respectively. Results show that some MA10 cells appeared rounded-up phenomenon with floating and membrane-blebbing after $24 \mathrm{hr}$ cordycepin $(100 \mu \mathrm{M}$ and $1 \mathrm{mM}$ ) treatment (Figure $7(\mathrm{a})$ ). In addition, MA-10 cells treated with $A_{1^{-}}, A_{2 A^{-}}, A_{2 B^{-}}$, and $A_{3}-A R$ agonists $(100 \mu \mathrm{M}, 25 \mu \mathrm{M}, 100 \mu \mathrm{M}$, and $50 \mu \mathrm{M}$, resp.) for $24 \mathrm{hr}$ also induced cells to have rounded-up phenomenon with floating cells (Figure $7(\mathrm{~b}))$. Cotreatment of cordycepin $(100 \mu \mathrm{M}$ and $1 \mathrm{mM})$ with $\mathrm{A}_{1^{-}}, \mathrm{A}_{2 \mathrm{~A}^{-}}$, and $\mathrm{A}_{2 \mathrm{~B}}$-agonists $(100 \mu \mathrm{M}, 25 \mu \mathrm{M}$, and $100 \mu \mathrm{M}$, resp.) for $24 \mathrm{hr}$ induced cells to have roundedup phenomenon with floating and membrane-blebbing. Interestingly, $\mathrm{A}_{3}$ - $\mathrm{AR}$ agonist $(50 \mu \mathrm{M})$ cotreated with cordycepin $(100 \mu \mathrm{M}$ and $1 \mathrm{mM})$ for $24 \mathrm{hr}$ would let some MA10 cell recover back to polygonal shape, which was similar to the control group (Figure 7(c)). MTT cytotoxicity assay was further employed to assess cell viability (Figure $7(\mathrm{~d})$ ). Compared to the control, $\mathrm{A}_{1}-\mathrm{AR}$ agonist, $\mathrm{CPA}$, at $100 \mu \mathrm{M}$ 

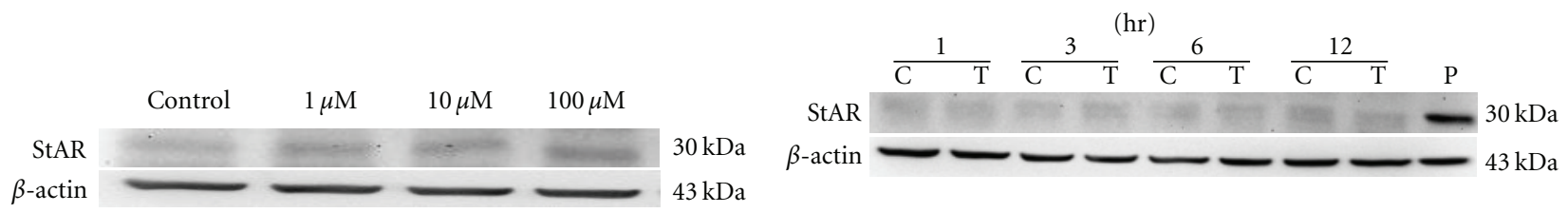

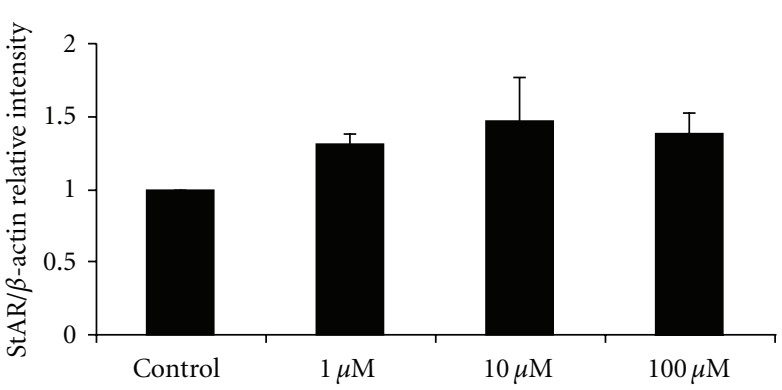

(a)

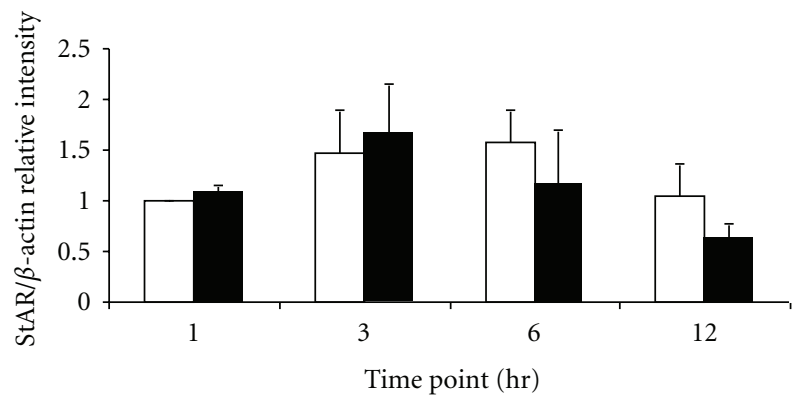

(b)

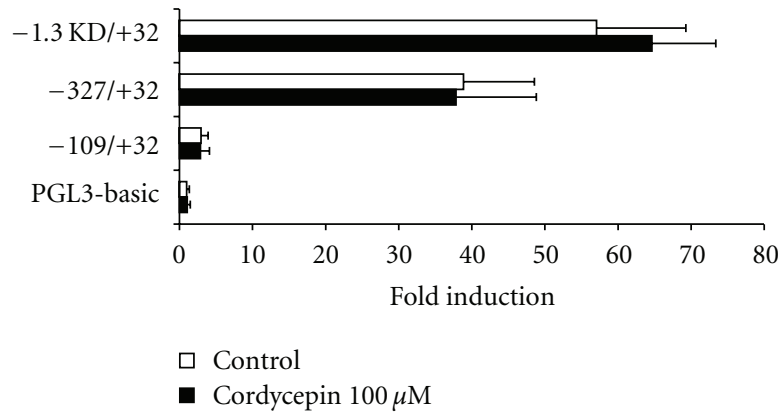

(c)

FIGURE 5: Effects of cordycepin on the expression of StAR protein and StAR promoter activity in MA-10 mouse Leydig tumor cells. MA-10 cells were treated with 1,10 , and $100 \mu \mathrm{M}$ cordycepin for $3 \mathrm{hr}$ (a); and MA-10 cells were treated with $100 \mu \mathrm{M}$ cordycepin for $1,3,6$, and $12 \mathrm{hr}$ (b), respectively. Treatment of hCG (1 IU) was used as a positive control. The expression of StAR ( $30 \mathrm{kDa})$ and $\beta$-actin $(43 \mathrm{kDa})$ detected by Western blotting. Quantitative analyses of the levels of StAR and $\beta$-actin $(\mathrm{a}, \mathrm{b})(n=3)$ are shown. Asterisk $*(P<.05)$ above the bars indicates significant difference compared with control. Serial deletion constructs of the StAR promoter were transiently transfected into MA-10 cells (c). The promoter activity was calculated by dividing firefly signals to Renilla signals. Each data point in the figure represents the mean \pm SEM of three independent experiments.

caused a significant reduction in cell viability to $73.8 \pm 5.2 \%$ $(P<.05) . \mathrm{A}_{2 \mathrm{~A}}$-AR agonist, CGS-21680, at $10 \mu \mathrm{M}$ and $25 \mu \mathrm{M}$ caused a significant reduction in cell viability to $84.9 \pm$ $2.4 \%$ and $78.4 \pm 4.0 \%$, respectively $(P<.05) . \mathrm{A}_{2 \mathrm{~B}}-\mathrm{AR}$ agonist, NECA, at $10 \mu \mathrm{M}$ and $100 \mu \mathrm{M}$ caused significant reductions in cell viability to $82.9 \pm 1.5 \%$ and $72.9 \pm 2.6 \%$, respectively $(P<.05)$. $\mathrm{A}_{3}-\mathrm{AR}$ agonist, IB-MECA, at $50 \mu \mathrm{M}$ caused a significant reduction in cell viability to $75.7 \pm 2.4 \%$ $(P<.05)$. These results showed that $\mathrm{A} 1-, \mathrm{A}_{2 \mathrm{~A}^{-}}, \mathrm{A}_{2 \mathrm{~B}^{-}}$, and A3-AR agonists significantly reduced MA-10 cell viability, respectively (Figure $7(\mathrm{~d}))(P<.05)$. Besides, cordycepin alone $(100 \mu \mathrm{M}$ and $1 \mathrm{mM})$ significantly decreased MA-10 cell viability approximately to $60 \%$ and $40 \%$, respectively, after $24 \mathrm{hr}$ treatment (Figure $7(\mathrm{e}))(P<.05)$. However, $\mathrm{A}_{1^{-}}, \mathrm{A}_{2 \mathrm{~A}^{-}}$, and $\mathrm{A}_{2 \mathrm{~B}}-\mathrm{AR}$ agonists plus cordycepin treatments did not have any additive effects on MA-10 cell death, respectively (Figure $7(\mathrm{e}))(P>.05)$. But, $\mathrm{A}_{3}-\mathrm{AR}$ agonist $(50 \mu \mathrm{M})$ cotreated with cordycepin $(100 \mu \mathrm{M}$ or $1 \mathrm{mM})$ would reverse MA-10 cell viability back to $81.6 \pm 9.6 \%$ or 61.6 $\pm 7.8 \%$, respectively (Figure $7(\mathrm{e})$ ). These results showed that $\mathrm{A}_{1^{-}}, \mathrm{A}_{2 \mathrm{~A}^{-}}, \mathrm{A}_{2 \mathrm{~B}^{-}}$, and $\mathrm{A}_{3}-\mathrm{AR}$ might be very important regarding the antitumor effects of cordycepin in MA-10 cells.

\subsection{AR Antagonists Could Prevent Cordycepin-Induced Cell} Death in MA-10 Mouse Leydig Tumor Cells . In order to confirm whether cordycepin-induced apoptosis was mediated via AR on MA-10 mouse Leydig tumor cells, cells were treated with cordycepin $(100 \mu \mathrm{M}$ and $1 \mathrm{mM})$ plus $\mathrm{A}_{1^{-}}, \mathrm{A}_{2 \mathrm{~A}^{-}}$, $\mathrm{A}_{2 \mathrm{~B}^{-}}$, and $\mathrm{A}_{3}-\mathrm{AR}$ antagonists (DPCPX, Caffeine, MRS1754 and MRS1191) for $24 \mathrm{hr}$, respectively. All $\mathrm{A}_{1^{-}}, \mathrm{A}_{2 \mathrm{~A}^{-}}, \mathrm{A}_{2 \mathrm{~B}}$, and $\mathrm{A}_{3}-\mathrm{AR}$ antagonists could let cordycepin-treated MA10 cells recover back to polygonal shape, which is similar to the cells in control group (Figure 8(a)). In MTT assay, the cotreatment of $100 \mu \mathrm{M}$ cordycepin with $1 \mu \mathrm{M} \mathrm{A} A_{1^{-}}$, $\mathrm{A}_{2 \mathrm{~A}^{-}}, \mathrm{A}_{2 \mathrm{~B}^{-}}$, and $\mathrm{A}_{3}-\mathrm{AR}$ antagonists could also significantly reverse cell viability to $90.6 \% \pm 3.8 \%, 89.2 \% \pm 4.8 \%$, $86.7 \% \pm 1.9 \%$ and $83.3 \% \pm 5.7 \%$, respectively $(P<.05)$ (Figure $8(\mathrm{~b})$ ). However, the cotreatment of $1 \mathrm{mM}$ cordycepin 


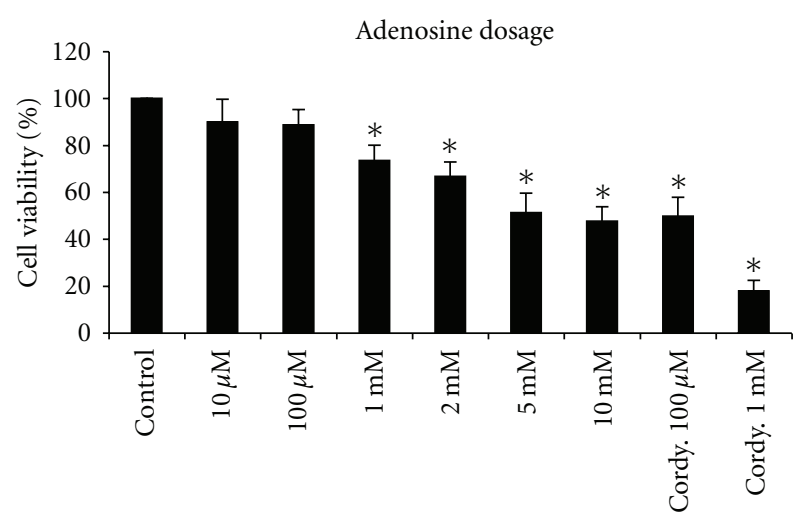

(a)

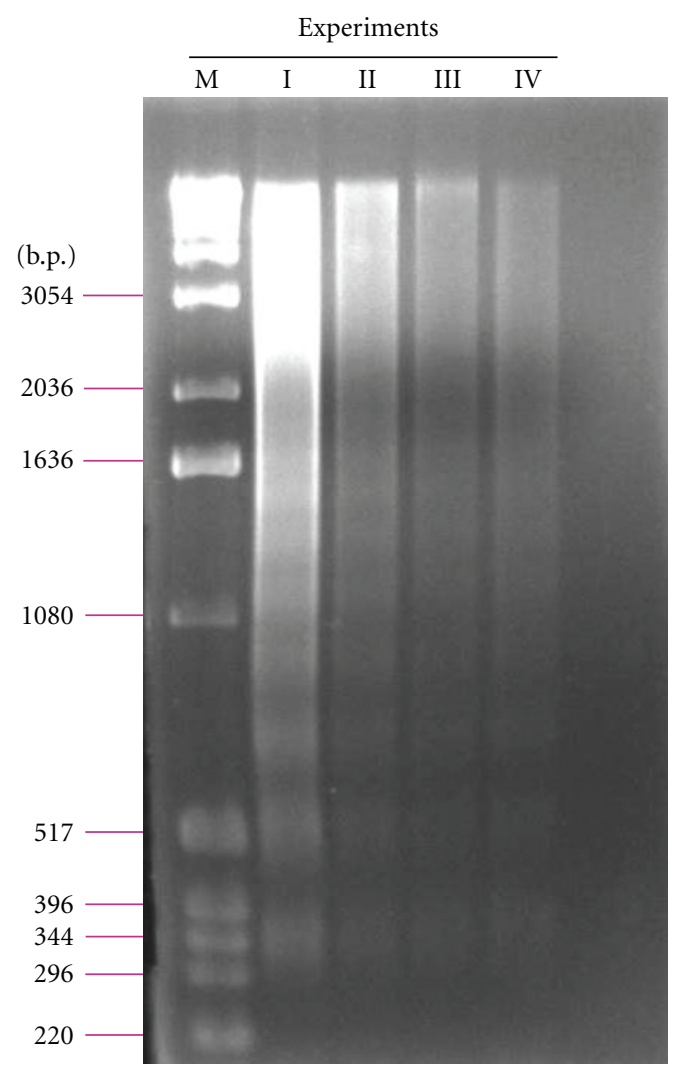

(b)

Figure 6: Effects of cordycepin and adenosine on cell death in MA-10 mouse Leydig tumor cells. MA-10 cells were cultured in medium without or with adenosine $(10 \mu \mathrm{M} \sim 10 \mathrm{mM}), 100 \mu \mathrm{M}$ and $1 \mathrm{mM}$ cordycepin for $48 \mathrm{hr}$ (a). MTT assay was performed to assess cell viability. Data represent the mean \pm SEM of four separate experiments. Asterisk * $(P<.05)$ above the bars indicates significant difference compared with control. (cordy. = cordycepin). (b) Gel electrophoresis of a $1 \mathrm{~kb}$ DNA ladder marker (lane $\mathrm{M}$ ) or DNA isolated from MA-10 cells that were cultured in the presence of $10 \mathrm{mM}$ adenosine for $48 \mathrm{hr}$. DNA was visualized by ethidium bromide staining and photographed under UV illumination. Experiments were performed four times (Exp. I-IV) with similar results. with $\mathrm{A}_{1^{-}}, \mathrm{A}_{2 \mathrm{~A}^{-}}, \mathrm{A}_{2 \mathrm{~B}^{-}}$, and $\mathrm{A}_{3}-\mathrm{AR}$ antagonists did not reverse cell viability (Figure $8(\mathrm{c})$ ). These results indicate that the apoptotic effects of cordycepin on MA-10 cells could be mediated by adenosine receptors.

\section{Discussion}

In this study, we demonstrate that cordycepin, a pure substance isolated from the Cordyceps sinensis, could stimulate steroidogenesis in MA-10 mouse Leydig tumor cells. Besides, cordycepin could induce the antitumor effect possibly through adenosine receptors in MA-10 mouse Leydig tumor cells.

First, we found that cordycepin increased the expression of $\mathrm{A}_{1^{-}}, \mathrm{A}_{2 \mathrm{~A}^{-}}$, and $\mathrm{A}_{3}-\mathrm{AR} \mathrm{mRNA}$ but decreased the expression of $\mathrm{A}_{2 \mathrm{~B}}-\mathrm{AR}$ mRNA at $24 \mathrm{hr}$ treatment. Under microscopic observation, we found that cordycepin-treated MA-10 cells exhibited cellular shrinkage and membrane blebbing, and finally cells detached from the dish. By MTT and DNA ladder assays, adenosine also significantly reduced MA-10 cell viability in a dose-dependent manner and induced DNA fragmentation. The effective concentration (EC50) of adenosine which could cause $50 \%$ inhibition of MA-10 cells growth was $5 \mathrm{mM}$ after $48 \mathrm{hr}$ treatment. However, we observed that the death effect of cordycepin was somewhat greater than adenosine in the same concentration $(100 \mu \mathrm{M}$ and $1 \mathrm{mM})$. These phenomena indicate that the apoptotic effect by adenosine in MA-10 cells was comparable.

Nakamura and coworkers have demonstrated that cordycepin inhibited lung carcinoma cells and melanoma cells growth by stimulating $A_{3}-A R[25,26]$. Many evidences have also illustrated that $A_{1}$ - and $A_{2 A}-A R$ expression mediated cell death by inducing apoptosis in breast carcinoma cells, astrocytoma cells, mouse thymocytes [29-31]. In this study, we showed that cordycepin could significantly stimulate the expression of $\mathrm{A}_{3}-\mathrm{AR}$ mRNA in cordycepin-treated MA10 cells. Moreover, this effect also occurred in $A_{1}-A R$ and $\mathrm{A}_{2 \mathrm{~A}}$-AR mRNA expressions. In addition, we also demonstrated that cordycepin induced MA-10 mouse Leydig tumor cell apoptosis through caspase- 9 and caspase-3 pathways [28]. These data suggested that AR might participate in cordycepin-induced apoptosis pathway in MA-10 mouse Leydig cells.

We continued to investigate the AR agonists to cotreat with cordycepin in MA-10 cells. We found that $A_{3}-A R$ agonists could significantly rescue cordycepin-induced apoptosis in MA-10 cells. Many reports indicate that adenosine displays contradictory effects such as the induction of cell apoptosis or stimulation of cell proliferation [32, 33]. It has been reported that the $\mathrm{A}_{3}$-AR agonist (CL-IB-MECA) reduced apoptosis in human astroglioma D384 cells [34]. In fact, some evidences have shown that adenosine via $A_{1}$-ARand $\mathrm{A}_{3}$-AR-mediated cytoprotection involves phospholipase $\mathrm{C}$, PKC, and p38 MAPK pathways, and reduced ROS production in cardiomyocytes [35-37]. In this study, we demonstrated that activation of AR would induce apoptosis in MA-10 cells. However, activation of different subtypes of 


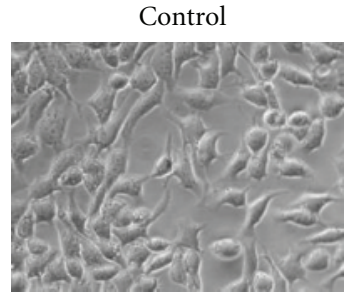

CPA

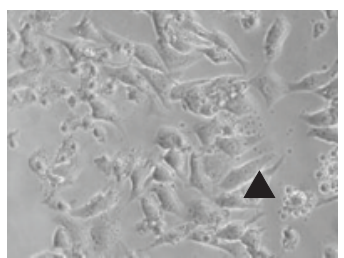

CPA
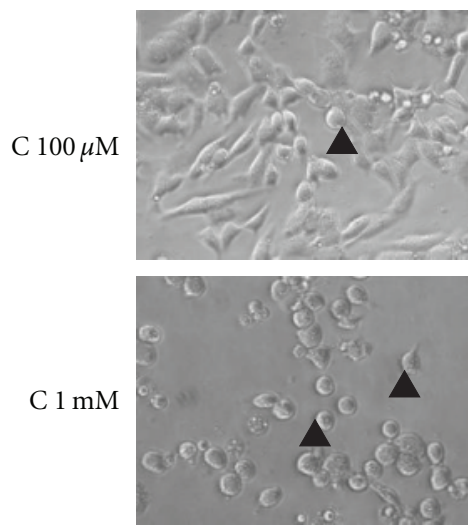

C $100 \mu \mathrm{M}$

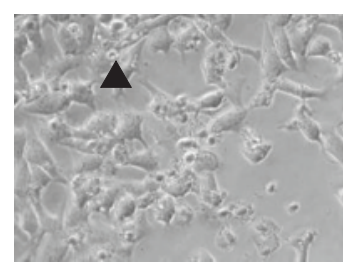

(b)
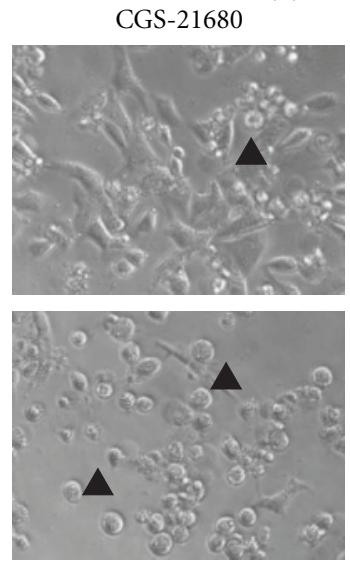

(c)

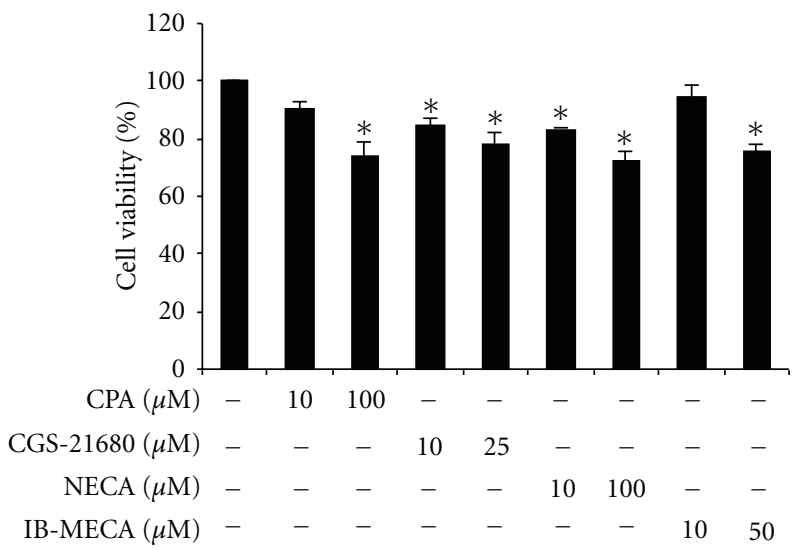

(d)

(a)
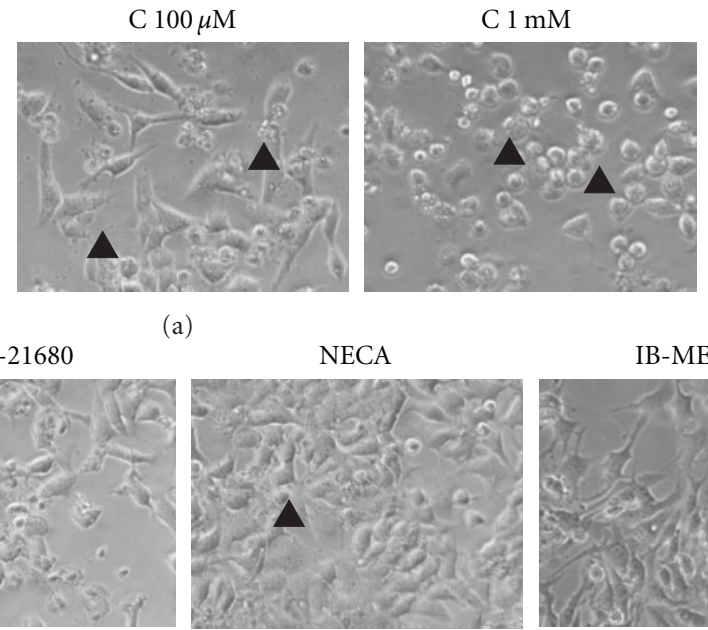

NECA
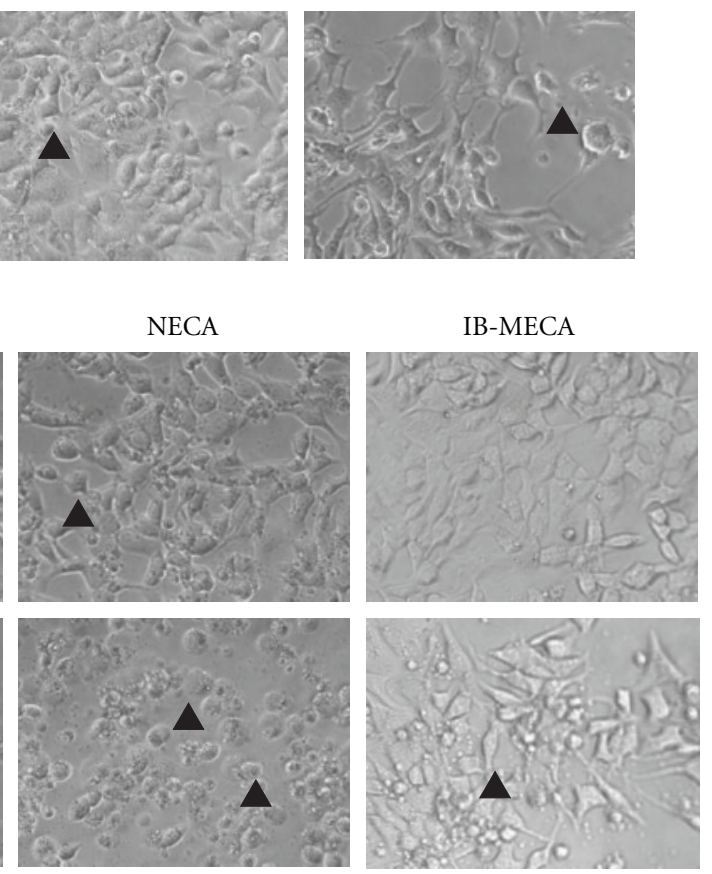

IB-MECA

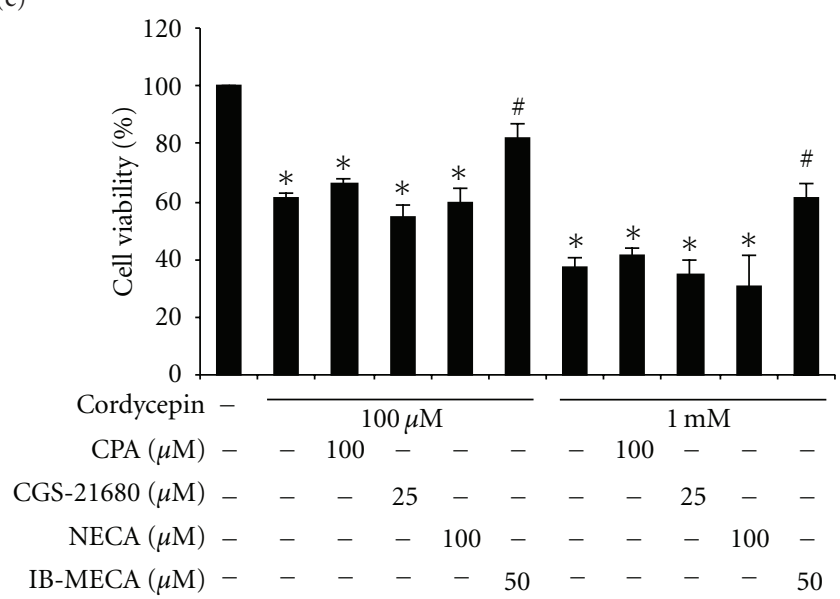

(e)

FIgURE 7: $A_{1}, A_{2 A}, A_{2 B}$, and $A_{3}$ AR were involved in cordycepin-induced cell death in MA-10 mouse Leydig tumor cells. MA-10 cells were treated with $A_{1}, A_{2 A}, A_{2 B}$, and $A_{3} A R$ agonists in the absence or presence of cordycepin for $24 \mathrm{hr}$. (a) shows that MA-10 cells were incubated in the absence or presence of cordycepin $(100 \mu \mathrm{M}$ and $1 \mathrm{mM})$ for $24 \mathrm{hr}$. (b) shows that MA-10 cells were incubated in $\mathrm{AR}$ agonists $\left(\mathrm{A}_{1} 100 \mu \mathrm{M}\right.$, $\mathrm{A}_{2 \mathrm{~A}} 25 \mu \mathrm{M}, \mathrm{A}_{2 \mathrm{~B}} 100 \mu \mathrm{M}$, and $\left.\mathrm{A}_{3} 50 \mu \mathrm{M}\right)$ for $24 \mathrm{hr}$. (c) shows that MA-10 cells were incubated in cordycepin (100 $\mu \mathrm{M}$ or $\left.1 \mathrm{mM}\right)$ plus AR agonists $\left(\mathrm{A}_{1} 10 \mu \mathrm{M}, \mathrm{A}_{2 \mathrm{~A}} 10 \mu \mathrm{M}, \mathrm{A}_{2 \mathrm{~B}} 10 \mu \mathrm{M}\right.$, and $\left.\mathrm{A}_{3} 50 \mu \mathrm{M}\right)$ for $24 \mathrm{hr}$. Cell morphology was observed and recorded under light microscopy (Olympus, CK 40). Note the same magnification (200x) among Figures. Arrowhead ( $\mathbf{\Delta})$ indicates rounded-up cells and/or membraneblebbed cells. MA-10 cells (5,000 cells/well) were treated with different dosages $(1 \sim 100 \mu \mathrm{M})$ of $\mathrm{A}_{1^{-}}, \mathrm{A}_{2 \mathrm{~A}^{-}}, \mathrm{A}_{2 \mathrm{~B}^{-}}$, and $\mathrm{A}_{3}$ - $\mathrm{AR}$ agonist in the absence (d) or presence of cordycepin $(100 \mu \mathrm{M}$ and $1 \mathrm{mM})$ for $24 \mathrm{hr}(\mathrm{e})$. MTT assay was used to assess cell viability, which was proportional to absorbance at $590 \mathrm{~nm}$. Each data point in the Figure represents the mean the mean \pm SEM of four independent experiments with triplicates in each treatment. Asterisk $*(P<.05)$ above the bars indicates significant difference compared with control. ${ }^{\#}(P<.05)$ above the bars indicates significant difference compared with cordycepin alone treatment group (C: cordycepin). 

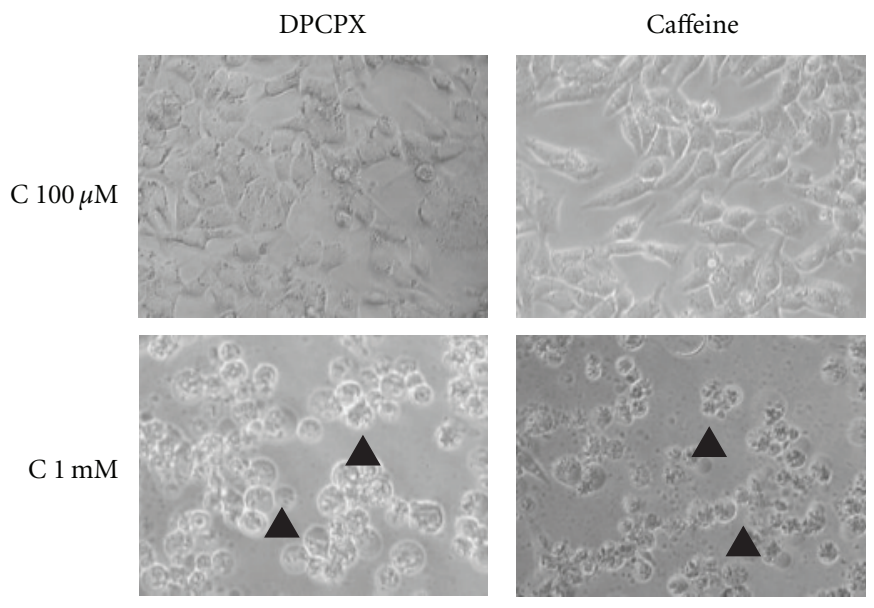

(a)

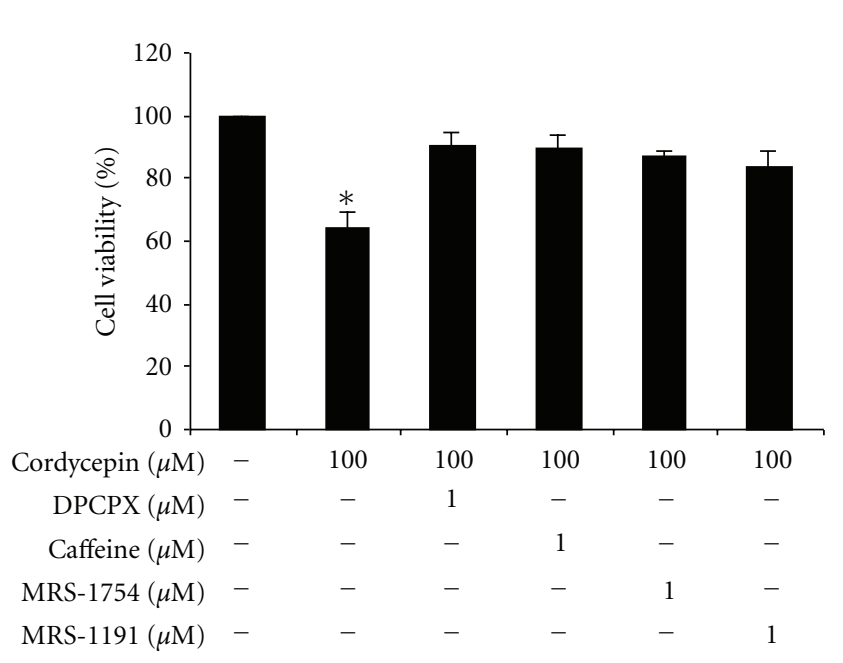

(b)

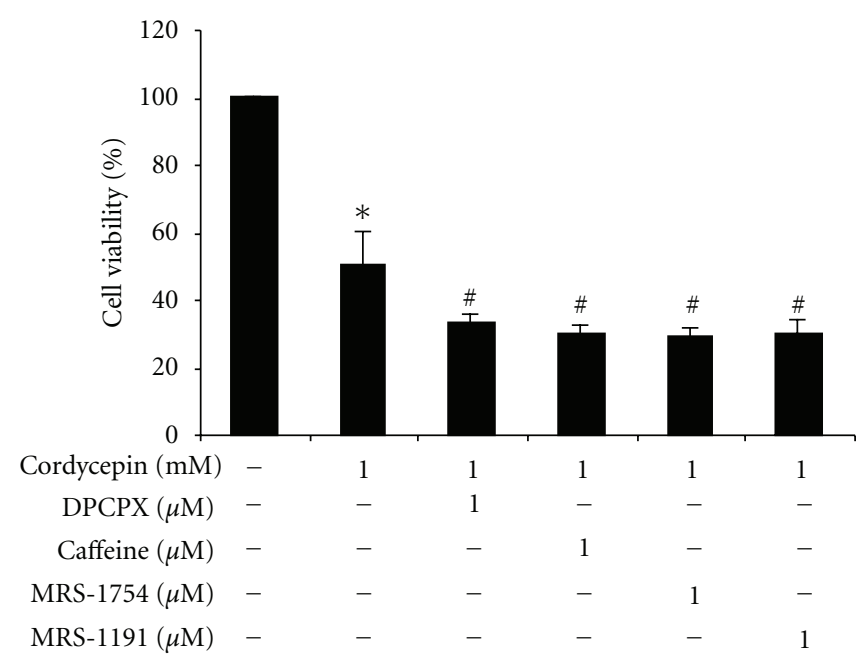

(c)

FIGURE 8: Effects of AR antagonists on cordycepin-induced cell death in MA-10 mouse Leydig tumor cells. MA-10 cells were treated with different adenosine receptor antagonists in the absence or presence of cordycepin for $24 \mathrm{hr}$. (a) shows that MA-10 cells were incubated in cordycepin $(100 \mu \mathrm{M}$ or $1 \mathrm{mM})$ plus $1 \mu \mathrm{M}$ selective AR antagonists for $24 \mathrm{hr}$. Cell morphology was observed and recorded under light microscopy (Olympus, CK 40). Note the same magnificantion (200×) among Figures. Arrowhead ( $\mathbf{\Delta})$ indicate rounded-up cells and/or membrane-blebbed cells. MA-10 cells (5,000 cells/well) were treated with different dosages $(1 \sim 100 \mu \mathrm{M})$ of $\mathrm{A}_{1^{-}}, \mathrm{A}_{2 \mathrm{~A}^{-}}, \mathrm{A}_{2 \mathrm{~B}^{-}}$, and $\mathrm{A}_{3}$-AR antagonists in the presence of $100 \mu \mathrm{M}$ (b) or $1 \mathrm{mM}$ (c) cordycepin for $24 \mathrm{hr}$. MTT assay was used to assess cell viability, which was proportional to absorbance at $590 \mathrm{~nm}$. Each data point in the Figure represents the mean the mean \pm SEM of four independent experiments with triplicates in each treatment. Asterisk $*(P<.05)$ above the bars indicates significant difference compared with control. ${ }^{\#}(P<.05)$ above the bars indicates significant difference compared with cordycepin alone treatment group (C: cordycepin).

AR could trigger apoptosis/survival pathway in MA-10 cells, which must be further investigated.

Recent reports demonstrated that adenosine receptor antagonists can resume cell viability on toxicant druginduced apoptosis in thyroid cancer cells [38, 39]. We used the selective AR antagonists to cotreat with cordycepin in MA-10 cells. We also demonstrated that $\mathrm{A}_{1^{-}}, \mathrm{A}_{2 \mathrm{~A}^{-}}, \mathrm{A}_{2 \mathrm{~B}^{-}}$, and $\mathrm{A}_{3}-\mathrm{AR}$ antagonist could significantly rescue $100 \mu \mathrm{M}$ cordycepin-induced apoptosis in MA-10 cells. These results indicate that the apoptotic effects of cordycepin on MA-10 cells could be mediated by AR. However, $1 \mathrm{mM}$ cordycepin cotreated with adenosine antagonists could not reverse cell viability, but even promote cell death. Recent developments of potent and selective antagonists of AR subtypes have been valuable for further defining the physiological effects of the various AR subtypes. Moreover, there are substantial species differences in the affinity of these compounds, and these selective compounds may fairly potent as antagonists of another AR subtypes [40].

It has been shown that adenosine-stimulated steroidogenesis might be involved in the $\mathrm{A}_{2 \mathrm{~A}^{-}}$and $\mathrm{A}_{2 \mathrm{~B}}-\mathrm{AR}$ and phosphorylation of MAPK ERK 1/2 signal pathway in rat adrenal cells [41]. Moreover, it is proposed that ligand binding results in a change in receptor state from an inactive to an active state will ultimately elicit its biological response based on the receptor's conformation [42]. In this model, 
agonists are thought to have selective binding affinity for the preexisting resting and active states or can induce a conformational change to a different receptor state and effects binding affinity of a ligand [43]. In the present study, cordycepin cotreated with $\mathrm{A}_{2 \mathrm{~B}}-\mathrm{AR}$ agonist (NECA) would significantly decrease NECA-stimulated progesterone production. It is probable that cordycepin may bind with other receptors and induce conformation change to effect binding affinity of $\mathrm{A}_{2 \mathrm{~B}}-\mathrm{AR}$ agonist. This result is consistent with the observation that cordycepin $(100 \mu \mathrm{M})$ decreased the expression of $\mathrm{A}_{2 \mathrm{~B}}-\mathrm{AR}$ mRNA at $24 \mathrm{hr}$ treatment. Although cordycepin $(100 \mu \mathrm{M})$ did not affect the expression of $\mathrm{A}_{1}$ and $A_{3}-A R$ mRNA, cordycepin cotreated with $A_{1}$ - and $A_{3}-$ AR agonist (CPA and IB-MECA) also significantly decreased their progesterone production. On the other hand, cordycepin did not affect the $\mathrm{A}_{2 \mathrm{~A}}-\mathrm{AR}$ agonist (CGS-21680)stimulated progesterone production. It is reasonable that cordycepin may compete with CGS-21680 in the same biding site of $\mathrm{A}_{2 \mathrm{~A}}$-AR to stimulate progesterone production. Here, we demonstrated that activation of $\mathrm{A}_{1^{-}}, \mathrm{A}_{2 \mathrm{~A}^{-}}, \mathrm{A}_{2 \mathrm{~B}^{-}}$, and $\mathrm{A}_{3}-\mathrm{AR}$ could induce steroidogenesis in MA-10. However, we used the AR antagonists to cotreat with cordycepin, and results illustrated huge variations. AR antagonists only slightly increased progesterone production than control group in MA-10 cells, which may decrease the accuracy. More experiments should be conducted to decrease the inconsistence.

Steroid production in Leydig and granulosa cells are regulated by various factors, including cAMP/PKA-dependent [44], mitogen-activated protein kinase/extracellular signalregulated kinase $1 / 2$ (MAPK ERK 1/2) $[45,46]$, and protein kinase $C(\mathrm{PKC})$ signaling pathways $[47,48]$. These kinases modulate cellular processes by phosphorylations. The family of MAPKs includes extracellular regulating kinase (ERK), c-Jun $\mathrm{NH}(2)$-terminal kinase (JNK), and p38, with each MAPK signaling pathway consisting of at least three components, a MAPK kinase kinase (MAP3k), a MAPK kinase (MAP2k), and a MAPK. Some reports have shown the stimulatory effects of MAPK ERK $1 / 2$ on steroidogenesis [ 49 , $50]$, and the others have demonstrated the inhibitory effects on steroidogenesis $[51,52]$. PKC signaling pathway can be activated by signals such as increases in the concentration of diacylglyceride (DAG), phospholipase C (PLC), or $\mathrm{Ca}^{2+}$ [53]. Recent reports indicate that $D A X-1$ gene interplay between the PKA/PKC signaling pathways and represses expression of StAR protein and steroidogenesis [54].

It is well established that StAR protein is essential for steroidogenesis, and that ERK $1 / 2$ phosphorylation driven by mitochondrial PKA will induce StAR protein expression and then steroidogenesis [46]. The previous data showed that cordycepin upregulates the expression of StAR mRNA and StAR protein to induce steroidogenesis through the PKA signaling pathway in normal mouse Leydig cells [55]. It has also been documented that the downstream effectors of PKA signaling pathway include several transcription factors [56]. However, our results indicated that cordycepin could not induce StAR protein and StAR promoter expressions in MA-10 cells. Our data are somewhat inconsistent to several studies that steroidogenesis could be trigger by cAMP and
StAR-independent pathways [57-59]. Therefore, it is possible that the cordycepin could possibly acitvate MAPK-ERK 1/2 and PKC pathways without increasing of StAR promoter and StAR protein expression to induce steroidogenesis in MA-10 cells, which will be worth to further investigate.

In conclusion, the present studies demonstrate that cordycepin is one of the active constituent of Cordyceps sinensis, which can stimulate progesterone production in MA-10 cells. Meanwhile, cordycepin could also activate AR and simultaneously induce steroidogenesis and apoptosis in MA-10 mouse Leydig tumor cells.

\section{Acknowledgment}

This work was supported by National Science Council Grants NSC98-2320-B-006-016 (to B.-M. Huang), Taiwan.

\section{References}

[1] X. Zhou, Z. Gong, Y. Su, J. Lin, and K. Tang, "Cordyceps fungi: natural products, pharmacological functions and developmental products," Journal of Pharmacy and Pharmacology, vol. 61, no. 3, pp. 279-291, 2009.

[2] Z. Q. He, J. Li, and D. Y. Cheng, "Effect of cordycepin on apoptosis and cell cycle in HeLa cells," Zhonghua Zhong Liu Za Zhi, vol. 31, no. 4, pp. 258-259, 2009.

[3] W. C. Wu, J. R. Hsiao, Y. Y. Lian, C. Y. Lin, and B. M. Huang, "The apoptotic effect of cordycepin on human OEC-M1 oral cancer cell line," Cancer Chemotherapy and Pharmacology, vol. 60, no. 1, pp. 103-111, 2007.

[4] H. Thomadaki, C. M. Tsiapalis, and A. Scorilas, "Polyadenylate polymerase modulations in human epithelioid cervix and breast cancer cell lines, treated with etoposide or cordycepin, follow cell cycle rather than apoptosis induction," Biological Chemistry, vol. 386, no. 5, pp. 471-480, 2005.

[5] H. Thomadaki, A. Scorilas, C. M. Tsiapalis, and M. Havredaki, "The role of cordycepin in cancer treatment via induction or inhibition of apoptosis: implication of polyadenylation in a cell type specific manner," Cancer Chemotherapy and Pharmacology, vol. 61, no. 2, pp. 251-265, 2008.

[6] Y. L. Huang, S. F. Leu, B. C. Liu, C. C. Sheu, and B. M. Huang, "In vivo stimulatory effect of Cordyceps sinensis mycelium and its fractions on reproductive functions in male mouse," Life Sciences, vol. 75, no. 9, pp. 1051-1062, 2004.

[7] Y. C. Chen, Y. L. Huang, and B. M. Huang, "Cordyceps sinensis mycelium activates PKA and PKC signal pathways to stimulate steroidogenesis in MA-10 mouse Leydig tumor cells," International Journal of Biochemistry and Cell Biology, vol. 37, no. 1, pp. 214-223, 2005.

[8] H. Y. Yang, S. F. Leu, Y. K. Wang, C. S. Wu, and B. M. Huang, "Cordyceps sinensis mycelium induces MA-10 mouse leydig tumor cell apoptosis by activating the caspase- 8 pathway and suppressing the NF- $\kappa \mathrm{B}$ pathway," Archives of Andrology, vol. 52, no. 2, pp. 103-110, 2006.

[9] H. K. Ghayee and R. J. Auchus, "Basic concepts and recent developments in human steroid hormone biosynthesis," Reviews in Endocrine and Metabolic Disorders, vol. 8, no. 4, pp. 289-300, 2007.

[10] N. Martinat, P. Crépieux, E. Reiter, and F. Guillou, "Extracellular signal-regulated kinases (ERK) 1,2 are required for luteinizing hormone ( $\mathrm{LH}$ )-induced steroidogenesis in primary Leydig cells and control steroidogenic acute regulatory (StAR) 
expression," Reproduction Nutrition Development, vol. 45, no. 1, pp. 101-108, 2005.

[11] P. R. Manna, J. Kero, M. Tena-Sempere, P. Pakarinen, D. M. Stocco, and I. T. Huhtaniemi, "Assessment of mechanisms of thyroid hormone action in mouse Leydig cells: regulation of the steroidogenic acute regulatory protein, steroidogenesis, and luteinizing hormone receptor function," Endocrinology, vol. 142, no. 1, pp. 319-331, 2001.

[12] F. Arakane, T. Sugawara, H. Nishino et al., "Steroidogenic acute regulatory protein (StAR) retains activity in the absence of its mitochondrial import sequence: implications for the mechanism of StAR action," Proceedings of the National Academy of Sciences of the United States of America, vol. 93, no. 24, pp. 13731-13736, 1996.

[13] D. M. Stocco, "Tracking the role of a StAR in the sky of the new millennium," Molecular Endocrinology, vol. 15, no. 8, pp. 1245-1254, 2001.

[14] D. M. Stocco, "The role of the StAR protein in steroidogenesis: challenges for the future," Journal of Endocrinology, vol. 164, no. 3, pp. 247-253, 2000.

[15] N. Cherradi, G. Defaye, and E. M. Chambaz, "Characterization of the $3 \beta$-hydroxysteroid dehydrogenase activity associated with bovine adrenocortical mitochondria," Endocrinology, vol. 134, no. 3, pp. 1358-1364, 1994.

[16] S. Sulimovici, B. Bartoov, and B. Lunenfeld, "Localization of 3 $\beta$ hydroxysteroid dehydrogenase in the inner membrane subfraction of rat testis mitochondria," Biochimica et Biophysica Acta, vol. 321, no. 1, pp. 27-40, 1973.

[17] B. B. Fredholm, G. Arslan, L. Halldner, B. Kull, G. Schulte, and W. Wasserman, "Structure and function of adenosine receptors and their genes," Naunyn-Schmiedeberg's Archives of Pharmacology, vol. 362, no. 4-5, pp. 364-374, 2000.

[18] S. M. Reppert, D. R. Weaver, J. H. Stehle, and S. A. Rivkees, "Molecular cloning and characterization of a rat A-adenosine receptor that is widely expressed in brain and spinal cord," Molecular Endocrinology, vol. 5, no. 8, pp. 1037-1048, 1991.

[19] Q. Y. Zhou, C. Li, M. E. Olah, R. A. Johnson, G. L. Stiles, and O. Civelli, "Molecular cloning and characterization of an adenosine receptor: the A3 adenosine receptor," Proceedings of the National Academy of Sciences of the United States of America, vol. 89, no. 16, pp. 7432-7436, 1992.

[20] S. A. Rivkees and S. M. Reppert, "RFL9 encodes an A(2b)adenosine receptor," Molecular Endocrinology, vol. 6, no. 10, pp. 1598-1604, 1992.

[21] J. H. Stehle, S. A. Rivkees, J. J. Lee, D. R. Weaver, J. D. Deeds, and S. M. Reppert, "Molecular cloning and expression of the cDNA for a novel A-adenosine receptor subtype," Molecular Endocrinology, vol. 6, no. 3, pp. 384-393, 1992.

[22] S. C. Chow, G. E. N. Kass, and S. Orrenius, "Purines and their roles in apoptosis," Neuropharmacology, vol. 36, no. 9, pp. 1149-1156, 1997.

[23] S. F. Leu, S. L. Poon, H. Y. Pao, and B. M. Huang, "The in vivo and in vitro stimulatory effects of cordycepin on mouse Leydig cell steroidogenesis," Bioscience Biotechnology, and Biochemistry, vol. 75, no. 4, pp. 723-731, 2011.

[24] O. H. Lowry, N. J. Rosebrough, A. L. Farr, and R. J. Randall, "Protein measurement with the Folin phenol reagent," The The Journal of Biological Chemistry, vol. 193, no. 1, pp. 265-275, 1951.

[25] K. Nakamura, N. Yoshikawa, Y. Yamaguchi, S. Kagota, K. Shinozuka, and M. Kunitomo, "Antitumor effect of cordycepin (3'-deoxyadenosine) on mouse melanoma and lung carcinoma cells involves adenosine A3 receptor stimulation," Anticancer Research, vol. 26, no. 1, pp. 43-47, 2006.
[26] N. Yoshikawa, S. Yamada, C. Takeuchi et al., "Cordycepin ( $3^{\prime}$-deoxyadenosine) inhibits the growth of B16-BL6 mouse melanoma cells through the stimulation of adenosine A3 receptor followed by glycogen synthase kinase- $3 \beta$ activation and cyclin D1 suppression," Naunyn-Schmiedeberg's Archives of Pharmacology, vol. 377, no. 4-6, pp. 591-595, 2008.

[27] B. M. Huang, S. Y. Ju, C. S. Wu, W. J. Chuang, C. C. Sheu, and S. F. Leu, "Cordyceps sinensis and its fractions stimulate MA-10 mouse leydig tumor cell steroidogenesis," Journal of Andrology, vol. 22, no. 5, pp. 831-837, 2001.

[28] B. M. Huang, C. Y. Jen, C. Y. Lin, and S. F. Leu, "Cordycepin induced MA-10 mouse leydig tumor cell apoptosis through caspase-9 pathway," Evidence-Based Complementary and Alternative Medicine, vol. 2011, Article ID 984537, 11 pages, 2011.

[29] A. Mirza, A. Basso, S. Black et al., "RNA interference targeting of A1 receptor-overexpressing breast carcinoma cells leads to diminished rates of cell proliferation and induction of apoptosis," Cancer Biology and Therapy, vol. 4, no. 12, pp. 1355-1360, 2005.

[30] I. Kiss, H. Oskolás, R. Tóth et al., "Adenosine A receptormediated cell death of mouse thymocytes involves adenylate cyclase and Bim and is negatively regulated by Nur77," European Journal of Immunology, vol. 36, no. 6, pp. 1559-1571, 2006.

[31] K. Sai, D. Yang, H. Yamamoto et al., "A adenosine receptor signal and AMPK involving caspase-9/-3 activation are responsible for adenosine-induced RCR-1 astrocytoma cell death," Neuro Toxicology, vol. 27, no. 4, pp. 458-467, 2006.

[32] M. Saito, T. Yaguchi, Y. Yasuda, T. Nakano, and T. Nishizaki, "Adenosine suppresses CW2 human colonic cancer growth by inducing apoptosis via A adenosine receptors," Cancer Letters, vol. 290, no. 2, pp. 211-215, 2010.

[33] P. Fishman, S. Bar-Yehuda, T. Farbstein, F. Barer, and G. Ohana, "Adenosine acts as a chemoprotective agent by stimulating G-CSF production: a role for $\mathrm{A} 1$ and $\mathrm{A} 3$ adenosine receptors," Journal of Cellular Physiology, vol. 183, no. 3, pp. 393-398, 2000.

[34] O. Björklund, M. Shang, I. Tonazzini, E. Daré, and B. B. Fredholm, "Adenosine A and A receptors protect astrocytes from hypoxic damage," European Journal of Pharmacology, vol. 596, no. 1-3, pp. 6-13, 2008.

[35] R. A. Fenton, L. G. Shea, C. Doddi, and J. G. Dobson, "Myocardial adenosine A-receptor-mediated adenoprotection involves phospholipase C, PKC-E, and p38 MAPK, but not HSP27," American Journal of Physiology, vol. 298, no. 6, pp. H1671-H1678, 2010.

[36] F. Xiang, Y. S. Huang, D. X. Zhang, Z. G. Chu, J. P. Zhang, and Q. Zhang, "Adenosine A receptor activation reduces opening of mitochondrial permeability transition pores in hypoxic cardiomyocytes," Clinical and Experimental Pharmacology and Physiology, vol. 37, no. 3, pp. 343-349, 2010.

[37] T. C. Zhao and R. C. Kukreja, "Protein kinase C- $\delta$ mediates adenosine A receptor-induced delayed cardioprotection in mouse," American Journal of Physiology, vol. 285, no. 1, pp. H434-H441, 2003.

[38] S. Morello, R. Sorrentino, A. Porta et al., "Cl-IB-MECA enhances TRAIL-induced apoptosis via the modulation of NF- $\kappa \mathrm{B}$ signalling pathway in thyroid cancer cells," Journal of Cellular Physiology, vol. 221, no. 2, pp. 378-386, 2009.

[39] G. Simonis, S. Wiedemann, D. Joachim, C. Weinbrenner, R. Marquetant, and R. H. Strasser, "Stimulation of adenosine $\mathrm{A} 2 \mathrm{~b}$ receptors blocks apoptosis in the non-infarcted myocardium even when administered after the onset of 
infarction," Molecular and Cellular Biochemistry, vol. 328, no. 1-2, pp. 119-126, 2009.

[40] J. Linden, "Molecular approach to adenosine receptors: receptor-mediated mechanisms of tissue protection," Annual Review of Pharmacology and Toxicology, vol. 41, pp. 775-787, 2001.

[41] W. Zhang, J. Li, S. Qiu, J. Chen, and Y. Zheng, "Effects of the exopolysaccharide fraction (EPSF) from a cultivated Cordyceps sinensis on immunocytes of H22 tumor bearing mice," Fitoterapia, vol. 79, no. 3, pp. 168-173, 2008.

[42] J. W. Black and P. Leff, "Operational models of pharmacological agonism," Proceedings of the Royal Society of London, vol. 220, no. 1219, pp. 141-162, 1983.

[43] H. P. Rang, "The receptor concept: pharmacology's big idea," British Journal of Pharmacology, vol. 147, no. 1, supplement, pp. S9-S16, 2006.

[44] M. T. Dyson, M. P. Kowalewski, P. R. Manna, and D. M. Stocco, "The differential regulation of steroidogenic acute regulatory protein-mediated steroidogenesis by type I and type II PKA in MA-10 cells," Molecular and Cellular Endocrinology, vol. 300, no. 1-2, pp. 94-103, 2009.

[45] Y. M. Lin, C. C. Tsai, C. L. Chung et al., "Fibroblast growth factor 9 stimulates steroidogenesis in postnatal Leydig cells," International Journal of Andrology, vol. 33, no. 3, pp. 545-553, 2010.

[46] C. Poderoso, P. Maloberti, A. Duarte et al., "Hormonal activation of a kinase cascade localized at the mitochondria is required for StAR protein activity," Molecular and Cellular Endocrinology, vol. 300, no. 1-2, pp. 37-42, 2009.

[47] P. R. Manna, S. P. Chandrala, S. R. King et al., "Molecular mechanisms of insulin-like growth factor-I mediated regulation of the steroidogenic acute regulatory protein in mouse leydig cells," Molecular Endocrinology, vol. 20, no. 2, pp. 362378, 2006.

[48] Y. Jo, S. R. King, S. A. Khan, and D. M. Stocco, "Involvement of protein kinase $\mathrm{C}$ and cyclic adenosine $3^{\prime}, 5^{\prime}$ - monophosphatedependent kinase in steroidogenic acute regulatory protein expression and steroid biosynthesis in Leydig cells," Biology of Reproduction, vol. 73, no. 2, pp. 244-255, 2005.

[49] S. L. Gyles, C. J. Burns, B. J. Whitehouse et al., "ERKs Regulate Cyclic AMP-induced Steroid Synthesis through Transcription of the Steroidogenic Acute Regulatory (StAR) Gene," The Journal of Biological Chemistry, vol. 276, no. 37, pp. 3488834895, 2001.

[50] S. Das, E. T. Maizels, D. Demanno, E. S. T. Clair, S. A. Adam, and M. Hunzicker-Dunn, "A stimulatory role of cyclic adenosine $3^{\prime}, 5^{\prime}$-monophosphate in follicle-stimulating hormoneactivated mitogen-activated protein Kinase signaling pathway in rat ovarian granulosa cells," Endocrinology, vol. 137, no. 3, pp. 967-974, 1996.

[51] R. Seger, T. Hanoch, R. Rosenberg et al., "The ERK Signaling Cascade Inhibits Gonadotropin-stimulated Steroidogenesis," The Journal of Biological Chemistry, vol. 276, no. 17, pp. 13957-13964, 2001.

[52] K. Tajima, A. Dantes, Z. Yao et al., "Down-regulation of steroidogenic response to gonadotropins in human and rat preovulatory granulosa cells involves mitogen-activated protein kinase activation and modulation of DAX-1 and steroidogenic factor-1," Journal of Clinical Endocrinology and Metabolism, vol. 88, no. 5, pp. 2288-2299, 2003.

[53] A. C. Newton, "Protein kinase C: poised to signal," American Journal of Physiology, vol. 298, no. 3, pp. E395-E402, 2010.

[54] P. R. Manna, M. T. Dyson, Y. Jo, and D. M. Stocco, "Role of dosage-sensitive sex reversal, adrenal hypoplasia congenita, critical region on the $\mathrm{x}$ chromosome, gene 1 in protein kinase a- and protein kinase c-mediated regulation of the steroidogenic acute regulatory protein expression in mouse leydig tumor cells: mechanism of action," Endocrinology, vol. 150, no. 1, pp. 187-199, 2009.

[55] C. C. Hsu, S. J. Tsai, Y. L. Huang, and B. M. Huang, "Regulatory mechanism of Cordyceps sinensis mycelium on mouse Leydig cell steroidogenesis," FEBS Letters, vol. 543, no. 1-3, pp. 140-143, 2003.

[56] W. A. Sands and T. M. Palmer, "Regulating gene transcription in response to cyclic AMP elevation," Cellular Signalling, vol. 20, no. 3, pp. 460-466, 2008.

[57] Y. O. Lukyanenko, A. M. Carpenter, D. E. Brigham, D. M. Stocco, and J. C. Hutson, "Regulation of Leydig cells through a steroidogenic acute regulatory protein-independent pathway by a lipophilic factor from macrophages," Journal of Endocrinology, vol. 158, no. 2, pp. 267-275, 1998.

[58] S. R. King, A. A. Matassa, E. K. White et al., "Oxysterols regulate expression of the steroidogenic acute regulatory protein," Journal of Molecular Endocrinology, vol. 32, no. 2, pp. 507-517, 2004.

[59] D. Gunnarsson, P. Leffler, E. Ekwurtzel, G. Martinsson, K. Liu, and G. Selstam, "Mono-(2-ethylhexyl) phthalate stimulates basal steroidogenesis by a cAMP-independent mechanism in mouse gonadal cells of both sexes," Reproduction, vol. 135, no. 5, pp. 693-703, 2008. 


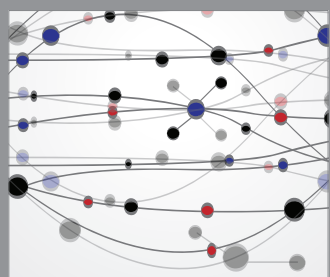

The Scientific World Journal
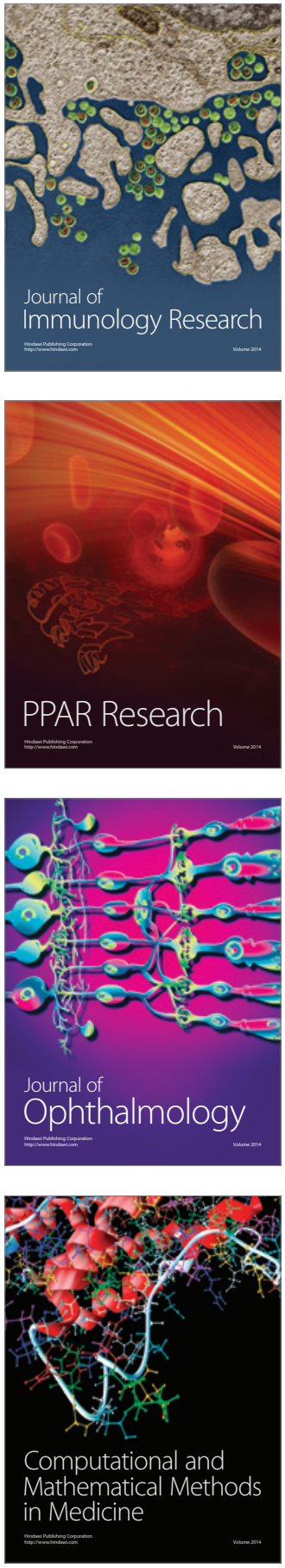

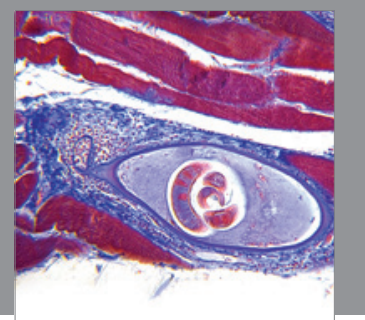

Gastroenterology

Research and Practice
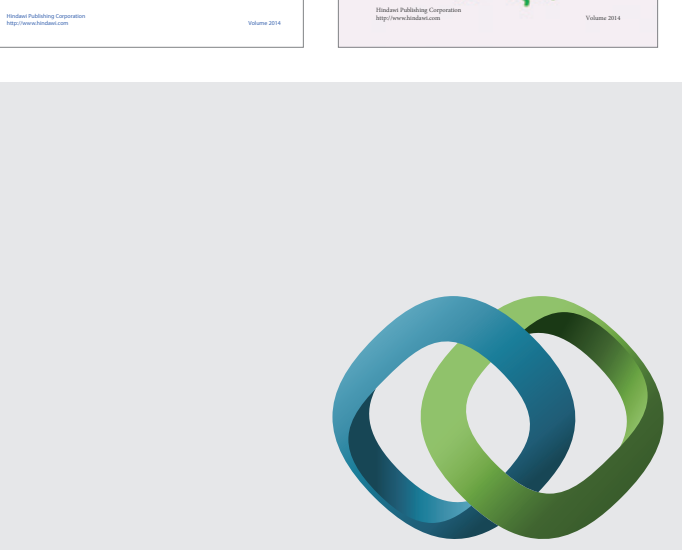

\section{Hindawi}

Submit your manuscripts at

http://www.hindawi.com
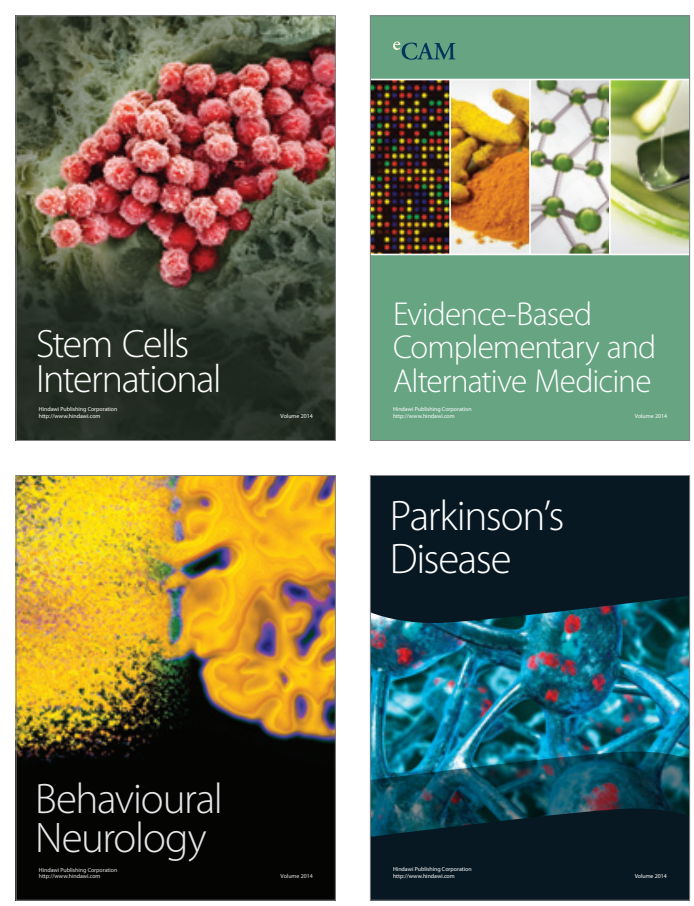

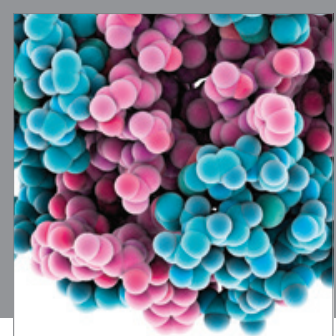

Journal of
Diabetes Research

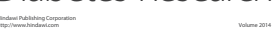

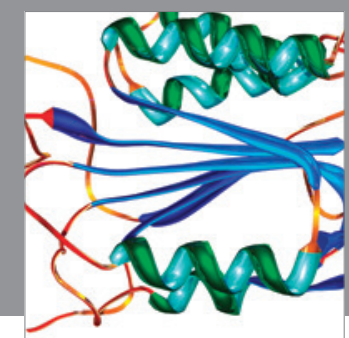

Disease Markers
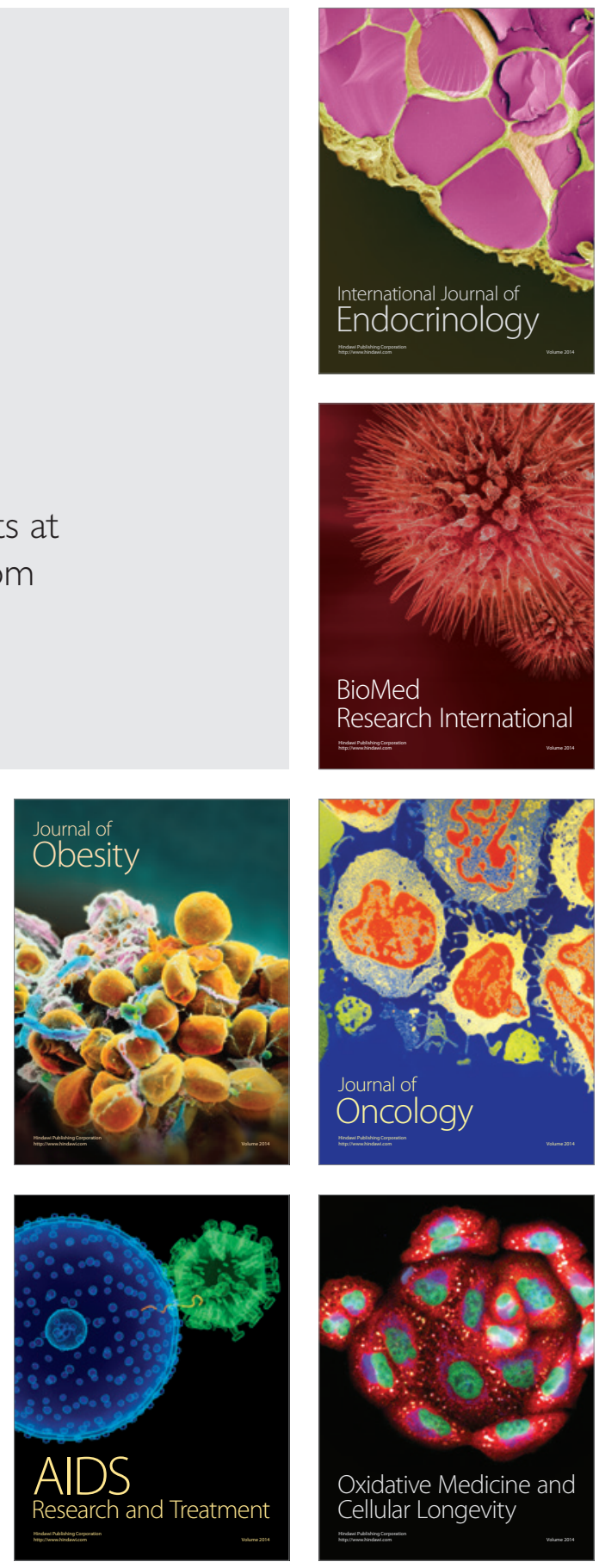